\title{
Review
}

\section{Mechanical Properties of Sustainable Metal Matrix Composites: A Review on the Role of Green Reinforcements and Processing Methods}

\author{
Sankaranarayanan Seetharaman ${ }^{1, *}$, Jayalakshmi Subramanian ${ }^{2} \mathbb{D}$, Ramachandra Arvind Singh ${ }^{2}$, \\ Wai Leong Eugene Wong ${ }^{3}$, Mui Ling Sharon Nai ${ }^{4}$ and Manoj Gupta ${ }^{5}$ (D)
}

Citation: Seetharaman, S.;

Subramanian, J.; Singh, R.A.; Wong,

W.L.E.; Nai, M.L.S.; Gupta, M.

Mechanical Properties of Sustainable Metal Matrix Composites: A Review on the Role of Green Reinforcements and Processing Methods. Technologies 2022, 10, 32. https://doi.org/ $10.3390 /$ technologies10010032

Academic Editor: Anders E.

W. Jarfors

Received: 5 January 2022

Accepted: 9 February 2022

Published: 16 February 2022

Publisher's Note: MDPI stays neutral with regard to jurisdictional claims in published maps and institutional affiliations.

Copyright: (C) 2022 by the authors. Licensee MDPI, Basel, Switzerland. This article is an open access article distributed under the terms and conditions of the Creative Commons Attribution (CC BY) license (https:// creativecommons.org/licenses/by/ $4.0 /$ )
1 Advanced Remanufacturing and Technology Centre, Agency for Science Technology and Research, Singapore 637143, Singapore

2 College of Mechanical and Electrical Engineering, Wenzhou University, Wenzhou 325035, China; jayalakshmi.subramanian@gmail.com (J.S.); arvind.nus@gmail.com (R.A.S.)

3 School of Mechanical and Systems Engineering, Newcastle University in Singapore, 172A Ang Mo Kio Ave 8, Singapore 567739, Singapore; eugene.wong@newcastle.ac.uk

4 Singapore Institute of Manufacturing Technology, Agency for Science Technology and Research, Singapore 637662, Singapore; mlnai@simtech.a-star.edu.sg

5 Department of Mechanical Engineering, National University of Singapore, 9 Engineering Drive 1, Singapore 117576, Singapore; mpegm@nus.edu.sg

* Correspondence: ssnseetharaman@yahoo.com

\begin{abstract}
Growing concerns like depleting mineral resources, increased materials wastage, and structural light-weighting requirements due to emission control regulations drive the development of sustainable metal matrix composites. $\mathrm{Al}$ and $\mathrm{Mg}$ based alloys with relatively lower melting temperatures qualify for recycling applications and hence are considered as the matrix material for developing sustainable composites. The recent trend also explores various industrial by-products and agricultural wastes as green reinforcements, and this article presents insights on the properties of $\mathrm{Al}$ and $\mathrm{Mg}$ based sustainable metal matrix composites with special emphasis on green reinforcements
\end{abstract} and processing methods.

Keywords: sustainability; metal matrix composites; green reinforcements; processing methods; mechanical properties

\section{Introduction}

Metal matrix composites belong to the class of advanced materials comprising two main components- a base material, i.e., matrix and one or more reinforcements for a good combination of properties that are hard to obtain by a single material. The improved mechanical strength, hardness, wear resistance, damping capacity, stiffness, ductility, thermal stability, creep resistance and toughness of metal matrix composites (MMCs) make them suitable for a wide range of applications. In particular, the weight saving potential of MMCs is highly desirable for use in ground transport and aviation sectors for structural weight reduction and associated reduction in fuel consumption. Other applications include cutting tools, marine, consumer electronics and package industries.

Depending on the intended application, a range of metallic alloys based on aluminium, magnesium, titanium, copper, nickel superalloys and steel can be used as the matrix material. In particular, the composites based on $\mathrm{Al}$ alloys with good strength to weight ratio and energy absorption capabilities receive enormous attention due to their weight saving potential (Figure 1). Table 1 lists the properties of few matrix materials. Though $\mathrm{Mg}$ is lighter than $\mathrm{Al}$, its wider adoption is largely restricted due to higher raw material and processing costs and the relatively poor corrosion resistance compared to Al alloys. Recent R\&D efforts are mostly aimed at addressing these issues. 


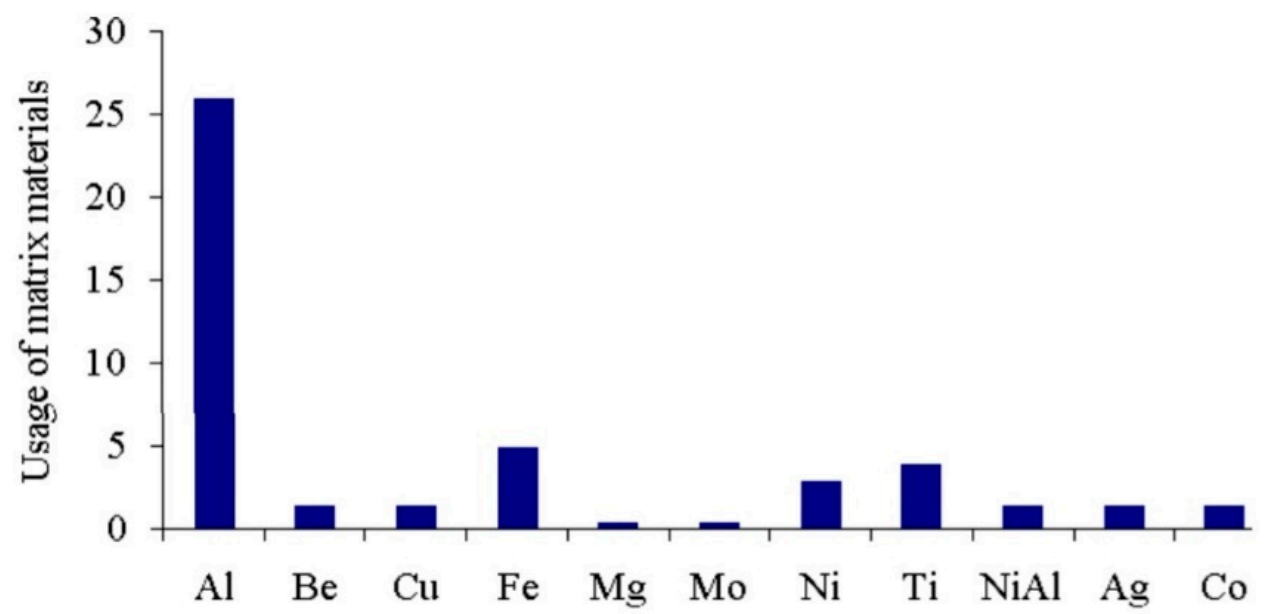

Figure 1. Use of matrix materials (From open access publication Adebisi et al. [1]).

Table 1. Properties of common matrix materials.

\begin{tabular}{ccccc}
\hline \multirow{2}{*}{ Metal } & Density & Yield Strength & Ductility & Modulus \\
\cline { 2 - 5 } & $\mathbf{( g / \mathbf { c m } ^ { \mathbf { 3 } } )}$ & $\mathbf{( M P a )}$ & $\mathbf{( \% )}$ & $\mathbf{( G P a )}$ \\
\hline Aluminum alloys & $2.5-2.9$ & $30-500$ & $1-44$ & $68-82$ \\
Magnesium alloys & $1.74-1.95$ & $70-400$ & $3.5-18$ & $42-47$ \\
Titanium alloys & $4.4-4.8$ & $250-1250$ & $1-40$ & $90-120$ \\
Ferrous alloys & $7.1-8.0$ & $240-690$ & $18-31$ & $187-215$ \\
Nickel alloys & $7.75-8.65$ & $300-1900$ & $0.5-60$ & $150-245$ \\
Copper alloys & $8.93-8.94$ & $30-500$ & $3-50$ & $112-148$ \\
\hline
\end{tabular}

Reinforcement materials are normally characterised by high strength, low density, and good thermal and chemical compatibility [2,3]. Common examples include ceramics, carbon compounds and hard metal refractories in the form of fibres or particles. They effectively take part in the load bearing process by sharing the load through interfacial load transfer [4]. The integration of continuous or discontinuous fibres offer strength in a preferred orientation. Based on the length of fibre, they can be further classified into long and short fibre reinforcement where the short fibres are known for providing better strength properties. In some cases, depending upon the nature of reinforcement and matrix material, coatings are used to either eliminate the undesirable chemical reactions occurring at the fibre-matrix interface or to improve the interfacial bonding and wetting characteristics. In particle reinforced MMCs, the addition of various ceramic and hard metal refractory particles with size ranging from few nanometres to few hundred micrometres, offer isotropic properties [4,5]. Table 2 highlights the key properties and applications of some of the commonly used reinforcements.

With the growing environmental concerns, there is also a strong push towards sustainable materials development. Processing of metallic materials alone have a huge impact on resource utilisation, emission, and waste generation. For example, the annual mining and primary production of steel and aluminium create around $2400 \mathrm{Mt}$ of tailings, $220 \mathrm{Mt}$ of steel slag, and $160 \mathrm{Mt}$ of bauxite residue [6]. With mineral extraction and by-products together with the excessive energy utilisation posing a serious threat for materials sustainability, any little efforts to reduce the environmental footprint of materials and manufacturing will significantly contribute towards the sustainability. For example, the effective recovery and utilisation of scrap material alone can account for more than one-third of our raw material needs. 
Table 2. Properties and applications of commonly used reinforcement materials.

\begin{tabular}{|c|c|c|c|c|c|c|}
\hline Reinforcement & Strength & Density & $\begin{array}{l}\text { Melting } \\
\text { Point }\end{array}$ & $\begin{array}{c}\text { Thermal } \\
\text { Conductivity }\end{array}$ & Remarks & Applications \\
\hline & (MPa) & $\left(\mathrm{g} / \mathrm{cm}^{3}\right)$ & $\left({ }^{\circ} \mathrm{C}\right)$ & (W/m-K) & & \\
\hline $\mathrm{SiC}$ & 1625 & 3.21 & 2730 & 20.7 & $\begin{array}{l}\text { High hardness, toughness, } \\
\text { wear resistance, } \\
\text { fatigue resistance }\end{array}$ & $\begin{array}{l}\text { Pistons, propeller shaft, } \\
\text { connecting rods, brake } \\
\text { rotors, driveshaft }\end{array}$ \\
\hline $\mathrm{B}_{4} \mathrm{C}$ & 569 & 2.52 & 2763 & 42 & $\begin{array}{l}\text { High melting point, low } \\
\text { specific weight, great } \\
\text { resistance to chemical agents }\end{array}$ & $\begin{array}{l}\text { Automobile sectors- intake, } \\
\text { manifolds, chassis, suspension } \\
\text { components, fast breeders, } \\
\text { lightweight armours }\end{array}$ \\
\hline $\mathrm{Al}_{2} \mathrm{O}_{3}$ & 665 & 3.95 & 2072 & 38.5 & $\begin{array}{l}\text { High specific stiffness, } \\
\text { fatigue strength }\end{array}$ & $\begin{array}{l}\text { Brake discs, pistons, cylinder } \\
\text { heads, connecting rods } \\
\text { of engine, }\end{array}$ \\
\hline Gr & 76 & 2.26 & 3600 & 114 & $\begin{array}{l}\text { Self-lubricating properties, } \\
\text { reduced friction }\end{array}$ & $\begin{array}{l}\text { Truss element, bus panel, } \\
\text { wave guides }\end{array}$ \\
\hline CNT & 63,000 & 1.3 & 3130 & 6000 & $\begin{array}{l}\text { High thermal and electrical } \\
\text { conductivity, high tensile } \\
\text { strength, low coefficient of } \\
\text { thermal expansion }\end{array}$ & $\begin{array}{l}\text { Thermal barrier coating, } \\
\text { anti-fouling, coating for ships, } \\
\text { biomedical applications, }\end{array}$ \\
\hline $\mathrm{Si}_{3} \mathrm{~N}_{4}$ & 76 & 3.25 & 2769 & 43 & $\begin{array}{l}\text { High strength, fracture } \\
\text { toughness at high temperature }\end{array}$ & $\begin{array}{c}\text { Turbo charger, rocker arm } \\
\text { pads, gas turbines, ceramics } \\
\text { hybrid bearings, } \\
\text { orthopaedic implants }\end{array}$ \\
\hline $\mathrm{TiB}_{2}$ & 373.6 & 4.54 & 3318 & 26 & $\begin{array}{l}\text { High elastic modulus, } \\
\text { strength, wear strength }\end{array}$ & $\begin{array}{l}\text { Ceramic cutting tools, } \\
\text { armours protection materials }\end{array}$ \\
\hline
\end{tabular}

With respect to metal matrix composites, $\mathrm{Al}$ and $\mathrm{Mg}$ with low energy requirements, qualify for material recycling benefit and their machined chips and scraps can be directly recycled as the matrix material. Similarly, there is also an increasing trend in exploring industrial by-products and agricultural wastes as green reinforcement to produce sustainable MMCs. Examples of green reinforcements includes basalt fibre from volcanic rocks, industrial fly ash residue, ash from the incineration of crop residue, and powders from natural shell materials like eggshell, snail shell etc. Several research works have been published on the use of industrial fly ash as reinforcement in MMC. Lancaster et al. [7] evaluated the potential of agro-based materials like coconut shell ash, rice husk etc. as reinforcement in MMCs. In addition to being cost effective, they exhibit comparable density, hardness, and thermal stability as they are mainly composed of $\mathrm{SiO}_{2}, \mathrm{Al}_{2} \mathrm{O}_{3}$, and $\mathrm{Fe}_{2} \mathrm{O}_{3}$. Further, they are naturally renewable at reasonable cost and offer greater potential for recycling unlike synthetic reinforcements that heavily depend on limited petroleum resources.

With up to $\sim 70 \%$ weight saving potential, sustainable metal matrix composites are also excellent candidates for electric vehicles to offset the additional mass of batteries. The use of renewable materials in automotive body parts will help to achieve stringent material recovery and recycling guidelines towards circular economy. Therefore, the automobile industry is highly appreciative of the R\&D efforts on lightweight sustainable composites. This article summarises the properties of $\mathrm{Al}$ and $\mathrm{Mg}$ based metal matrix composites reinforced with various natural and industrial waste materials.

\section{Basalt Fibre Reinforced Metal Matrix Composites}

Basalt fibres are obtained by melting and drawing of basalt rock which is a natural igneous rock formed by the rapid cooling of volcanic lava. It has a melting temperature greater than $1500{ }^{\circ} \mathrm{C}$ and density about $2.7 \mathrm{~g} / \mathrm{cc}$. Although manufacturing processes applicable for basalt fibre are based on traditional melt spinning and blowing technologies, they consume less energy and additives. Therefore, their production cost is significantly low compared to glass balloons and carbon fibres. As the chemical composition of basalt fibre is similar to asbestos (Tables 3 and 4), several studies evaluated their health hazards and concluded that the basalt fibres do not any pose serious risks to human beings due to the difference in morphology and surface properties [8,9]. With respect to properties, 
basalt fibres have comparable load bearing capabilities and weight saving advantages as E-Glass. In addition, they also exhibit good compatibility with most matrix materials and remain resistant to acid exposure and high temperatures $[10,11]$ which makes it ideal for developing fibre reinforced composites.

While the basalt fibres are used widely in polymer matrix composites, only few studies explored their applicability for MMCs which was mainly attributed to the processing difficulties. Using the method of stir casting, aluminium (7075) alloy composites containing different volume fraction of short basalt fibres (length 1.5-2 mm) were developed for the first time by Karthigeyan et al. [12] The composites showed improvement in strength properties due to the homogeneous distribution of basalt fibres and second phase precipitates in $\mathrm{Al}$ matrix (Table 5). The optimum reinforcement content for Al 7075 alloy was identified to be 6 vol.\% short basalt fibre. Copper coating on basalt fibres improved the interfacial properties of the composites [13].

Table 3. Composition of basalt fiber [12].

\begin{tabular}{cc}
\hline Constituent & Composition (wt.\%) \\
\hline $\mathrm{SiO}_{2}$ & $42-56$ \\
$\mathrm{Al}_{2} \mathrm{O}_{3}$ & $11-18$ \\
$\mathrm{Fe}_{2} \mathrm{O}_{3}$ & $<12$ \\
$\mathrm{CaO}$ & $7-12$ \\
$\mathrm{MgO}$ & $4-11$ \\
$\mathrm{Na}_{2} \mathrm{O}$ & $2-5$ \\
$\mathrm{TiO}_{2} / \mathrm{K}_{2} \mathrm{O}$ & $1-5$ \\
\hline
\end{tabular}

Table 4. Properties of E-glass and basalt fiber [14].

\begin{tabular}{ccc}
\hline Properties & E-Glass & Basalt \\
\hline Density $\left(\mathrm{g} / \mathrm{cm}^{3}\right)$ & 2.56 & 2.8 \\
Elastic modulus $(\mathrm{GPa})$ & 76 & 89 \\
Tensile strength $(\mathrm{GPa})$ & $1.4-2.5$ & 2.8 \\
Elongation to fracture $(\%)$ & $1.8-3.2$ & 3.15 \\
Specific E modulus $\left(\mathrm{GPa}\right.$ per $\left.\mathrm{g} / \mathrm{cm}^{3}\right)$ & 30 & 31.78 \\
Specific tensile strength $\left(\mathrm{GPa}\right.$ per $\left.\mathrm{g} / \mathrm{cm}^{3}\right)$ & $0.5-1$ & 1 \\
\hline
\end{tabular}

Table 5. Properties of Basalt fiber reinforced Al7075 composites [13].

\begin{tabular}{cccc}
\hline \multirow{2}{*}{ Material } & Yield Strength & Tensile Strength & Ductility \\
\cline { 2 - 4 } & $\mathbf{( M P a )}$ & $\mathbf{( M P a )}$ & $\mathbf{( \% )}$ \\
\hline Al 7075 & $107 \pm 3$ & $127 \pm 4$ & 1.55 \\
Al 7075-2\% SBF & $112 \pm 2$ & $130 \pm 3$ & 1.49 \\
Al 7075-4\% SBF & $128 \pm 2$ & $162 \pm 5$ & 1.52 \\
Al 7075-6\% SBF & $180 \pm 5$ & $212 \pm 3$ & 1.58 \\
\hline
\end{tabular}

Investigations on the properties of basalt fibre reinforced A413 alloy-based Al matrix composite were carried out by direct impregnation of basalt fibre bundles with molten alloy followed by hot pressing of composite layers [15]. Here, the strength properties were reduced at higher processing temperatures and longer holding time. Despite the stability of basalt fibres at high processing temperatures, the difference in deformation and flow behaviour resulted in porosity and void fractions which lead to a higher percentage of defects and strength loss. Up to 28 vol. \% of basalt fibres (diameter $10 \mu \mathrm{m}$ ) were incorporated into A413 alloy by via hand lay-out and hot-pressing technique [16]. The fibre content had a reverse effect on the density of composites. Short basalt fibres-Al alloy matrix composites produced by squeeze infiltration method revealed homogeneous dispersion of reinforcement and decrease in ductility with increase in volume fraction [17]. 


\section{Red Mud Reinforced Metal Matrix Composites}

Red mud, the mining waste from aluminium production is also a potential reinforcing material to prepare MMCs. It is mainly composed of insoluble metal oxides based on Fe and Al. Table 6 shows the typical chemical composition of Red mud and the actual composition depends on the quality and nature of the bauxite ore and the extraction conditions.

Table 6. Composition of red mud from [18].

\begin{tabular}{ccccccccc}
\hline Elements & $\mathrm{Fe}_{2} \mathrm{O}_{3}$ & $\mathrm{Al}_{\mathbf{2}} \mathrm{O}_{3}$ & $\mathrm{SiO}_{2}$ & $\mathrm{Na}_{\mathbf{2}} \mathrm{O}$ & $\mathrm{TiO}_{2}$ & $\mathrm{CaO}$ & $\mathbf{V}_{\mathbf{2}} \mathrm{O}_{5}$ & Others \\
\hline Content (\%) & 53.8 & 14.3 & 8.34 & 4.3 & 3.9 & 2.5 & 0.38 & Bal. \\
\hline
\end{tabular}

Pure Al based composites with red mud particles were produced using powder metallurgy route [18]. In this study, the effects of variation in particle size $(42 \mathrm{~nm}, 100 \mu \mathrm{m}$, $150 \mu \mathrm{m}, 200 \mu \mathrm{m})$ and weight percentage (2-6\%) of red mud particles were studied in terms of hardness (Table 7) and compression strength. Increasing amounts of red mud particles resulted in an increase in hardness and compression strength. Further, the nanosized particles provided superior strengthening effects compared to micron size particles.

Table 7. Effect of red mud weight percentage \& particle size on the hardness of Al [18].

\begin{tabular}{ccccc}
\hline \multirow{2}{*}{$\begin{array}{c}\text { Red Mud } \\
\text { (wt. \%) }\end{array}$} & $\mathbf{1 0 0} \boldsymbol{\mu m}$ & $\mathbf{1 5 0} \boldsymbol{\mu m}$ & $\mathbf{2 0 0} \boldsymbol{\mu m}$ & $\mathbf{0 . 0 4 2} \boldsymbol{\mu m}$ \\
\cline { 2 - 5 } & 60.2 & 58.3 & 56.7 & 73.6 \\
4 & 67.6 & 62.4 & 59.3 & 77.4 \\
6 & 74.5 & 69.2 & 63.5 & 83.9 \\
\hline
\end{tabular}

Using stir casting method, Harshavardhan et al. [19] developed Al 8011 alloy based composite reinforced with red mud particles and investigated microstructure, hardness, and fracture toughness. While the microstructure had fairly uniform distribution of red mud particles, hardness varied from $60.2 \mathrm{HVN}$ to $74.5 \mathrm{HVN}$ with an increase in reinforcement content from $2 \%$ to $6 \%$. Further, addition of nanosized particles increased the hardness by $\sim 11 \%$ compared to particles of size $100 \mu \mathrm{m}$. Compact tension and single notched bending test-based fracture toughness values showed an increased load bearing capacity by $35 \%$ for $12 \mathrm{wt} . \%$ red mud. A similar trend was observed for the stress intensity factor K1C.

Stir cast AA 6082 alloy based composite reinforced with up to $6 \mathrm{wt} . \%$ red mud particles was produced to investigate the effect of heat treatment on microstructure, hardness and tensile properties [20]. The uniform distribution of red mud particles increased the Vickers hardness (an increase from 80.3 to $92.1 \mathrm{HV}$ and 88.4 to $104.3 \mathrm{HV}$ ), and tensile strength values (Table 8 ) in both the as cast and heat-treated conditions. Under dry sliding tribological test conditions, wear resistance increased due to red mud particle addition [21]. Delamination and abrasion were the dominant wear mechanisms. However, under impact loading conditions, both as cast and heat-treated composites showed loss in impact strength.

Erosive wear behaviour of red mud reinforced $\mathrm{Al}$ matrix composites at different impingement angles from $30^{\circ}$ to $90^{\circ}$ with different pressures and standoff distances (SOD) were reported by Acharya et al. [22], wherein (i) 30\% red mud particle showed and (ii) $45^{\circ}$ impingement angle resulted in maximum wear rate and brittle behaviour.

In another study, slag from blast furnace slag was used in combination with red mud particles as a reinforcement in Al alloy AA2024 [23]. The combined addition of $2 \%$ blast furnace slag and $3 \%$ red mud improved the Vickers hardness, tensile and compressive strengths of AA2024 alloy by $4 \%, 6 \%$ and $36 \%$ respectively (Table 9), while the shear strength was improved by $8 \%$. The microstructural observations confirm the uniform distribution of reinforcement. 
Table 8. Tensile properties of as cast (AC) and heat-treated (HT) red mud reinforced AA6082 composites [20].

\begin{tabular}{ccccccc}
\hline \multirow{2}{*}{$\begin{array}{c}\text { Red Mud } \\
\text { (wt. } \%)\end{array}$} & \multicolumn{2}{c}{ Yield Strength } & \multicolumn{2}{c}{ Tensile Strength } & \multicolumn{2}{c}{ Elongation } \\
\cline { 2 - 7 } & \multicolumn{2}{c}{$\mathbf{( M P a )}$} & \multicolumn{2}{c}{$\mathbf{( M P a )}$} & \multicolumn{2}{c}{$\mathbf{( \% )}$} \\
\hline & AC & HT & AC & HT & AC & HT \\
\hline 0 & 89.14 & 94.61 & 141.23 & 158.25 & 10.32 & 8.6 \\
\hline 2 & 94.72 & 99.36 & 148.68 & 162.54 & 8.81 & 7.45 \\
\hline 4 & 102.63 & 111.21 & 152.5 & 169.72 & 6.50 & 5.2 \\
\hline 6 & 112.05 & 119.35 & 169.87 & 179.50 & 5.12 & 4.53 \\
\hline
\end{tabular}

Table 9. Tensile strength of basalt fiber and red mud reinforced Al based composites [23].

\begin{tabular}{cc}
\hline Composition & Tensile Strength (MPa) \\
\hline Al-4Bf-1RM & 389.34 \\
Al-3BF-2RM & 403.58 \\
Al-2BF-3RM & 497.23 \\
\hline
\end{tabular}

\section{Fly Ash Reinforced Metal Matrix Composites}

Fly ash is a fine residue captured from the flue gases of coal-fired power plants. It forms about $40 \%$ of all the waste in coal combustion products and is therefore available in large quantities. Lancaster et al. [7] studied the chemical composition of untreated and treated fly ash reinforcement using $\mathrm{X}$-ray fluorescent spectroscopy and the results revealed the present of hard ceramic phases like $\mathrm{SiO}_{2}, \mathrm{Al}_{2} \mathrm{O}_{3}, \mathrm{Fe}_{2} \mathrm{O}_{3}, \mathrm{CaO}, \mathrm{MgO}$ and $\mathrm{BaO}$ (Table 10). According to ASTM standard C618, fly ash can be grouped into three major classes based on the actual composition as shown in Table 11.

Table 10. Composition of fly ash reinforcement before and after treatment [7].

\begin{tabular}{ccccccc}
\hline Condition & $\mathrm{Al}_{2} \mathbf{O}_{3}$ & $\mathbf{B a O}$ & $\mathbf{C a O}$ & $\mathrm{Fe}_{\mathbf{2}} \mathbf{O}_{3}$ & $\mathbf{M g O}$ & $\mathbf{S i O}_{2}$ \\
\hline Before & 29.6 & 0.1 & 0.72 & 3.53 & 0.34 & 64.6 \\
After & 25.6 & 1.0 & 0.69 & 3.14 & 0.56 & 69.5 \\
\hline
\end{tabular}

Table 11. Classification of fly ash cenospheres [24].

\begin{tabular}{cccc}
\hline \multirow{2}{*}{ Composition } & \multicolumn{3}{c}{ Class } \\
\cline { 2 - 4 } & $\mathbf{N}$ & $\mathbf{F}$ & $\mathbf{C}$ \\
\hline $\mathrm{SiO}_{2}+\mathrm{Al}_{2} \mathrm{O}_{3}+\mathrm{Fe}_{2} \mathrm{O}_{3}$ & 70 & 50 & 50 \\
$\mathrm{CaO}$ & Negligible & 18 & $>18$ \\
$\mathrm{SO}_{3}$ & 4 & 5 & 5 \\
Moisture & 3 & 3 & 3 \\
\hline
\end{tabular}

Because of the serious breathing hazard and damages to environment, fly ash disposal is expensive and the products that utilize fly ash are broadly regarded as eco-friendly. In general, fly ash is primarily used in cement making which is non-hazardous and the other applications include soil stabilization, structural fill, mineral filler for asphalt roads, flowable fill, geopolymers, bricks and waste treatment. There are two categories of fly ash particles: (i) solid particles with a density $2.55 \mathrm{~g} / \mathrm{cc}$, and (ii) hollow cenospheres with density ranges between 0.5 and $0.9 \mathrm{~g} / \mathrm{cc}$. The low density of (i) and (ii) makes fly ash an excellent choice as low-cost green reinforcement to develop lightweight MMCs. For example, the replacement of $20 \mathrm{wt} . \% \mathrm{Al}$ by hollow fly ash to produce $\mathrm{Al}$ composite is expected to save around $38.86 \mathrm{kWh}$ energy per $\mathrm{kg}$ of finished $\mathrm{Al}$ casting [25]. The complex chemical composition of fly ash particles favors a large number of thermodynamically 
spontaneous reactions as shown in Equations (1)-(7) below. While some of the resulting intermetallics like $\mathrm{MgSi}_{2}$ are beneficial, the formation of undesirable brittle phases like $\mathrm{Al}_{5} \mathrm{FeSi}$ and $\mathrm{Al}_{15}(\mathrm{Fe}, \mathrm{Mn})_{3} \mathrm{Si}_{2}$ combined with the hollow structure of fly ash particles present multiple challenges during the processing of MMCs. Figure 2 shows a hollow cenosphere fly ash particle of particle size 10-100 $\mu \mathrm{m}$.

$$
\begin{aligned}
& 4 \mathrm{Al}_{(\mathrm{l})}+3 \mathrm{SiO}_{2(\mathrm{~s})} \leftrightarrow 3 \mathrm{Si}_{(\mathrm{s})}+2 \mathrm{Al}_{2} \mathrm{O}_{3(\mathrm{~s})}\left(\Delta \mathrm{G}^{\circ}=-532.2 \mathrm{KJ} \mathrm{mol}^{-1}\right) \\
& 2 \mathrm{Al}_{(\mathrm{l})}+\mathrm{Fe}_{2} \mathrm{O}_{3(\mathrm{~s})} \leftrightarrow 2 \mathrm{Fe}_{(\mathrm{s})}+2 \mathrm{Al}_{2} \mathrm{O}_{3(\mathrm{~s})}\left(\Delta \mathrm{G}^{\circ}=-799.6 \mathrm{KJ} \mathrm{mol}^{-1}\right) \\
& 3 \mathbf{M g}_{(\mathbf{l})}+4 \mathrm{Al}_{2} \mathbf{O}_{3(\mathrm{~s})} \leftrightarrow 2 \mathrm{Al}_{(\mathrm{s})}+3 \mathrm{MgAl}_{2} \mathbf{O}_{4(\mathbf{s})}\left(\Delta \mathbf{G}^{\circ}=-215.1 \mathrm{KJ} \mathrm{mol}^{-1}\right) \\
& 3 \mathrm{SiO}_{2(\mathbf{s})}+2 \mathrm{Mg}_{(\mathrm{l})} \leftrightarrow 2 \mathrm{MgO}_{(\mathrm{s})}+\mathbf{S i}_{(\mathrm{s})}\left(\Delta \mathbf{G}^{\circ}=-255.6 \mathrm{KJ} \mathrm{mol}^{-1}\right) \\
& 2 \mathrm{SiO}_{2(\mathrm{~s})}+2 \mathrm{Al}_{(\mathrm{l})}+\mathrm{Mg}_{(\mathrm{l})} \leftrightarrow \mathrm{MgAl}_{2} \mathrm{O}_{4(\mathrm{~s})}+2 \mathrm{Si}_{(\mathrm{s})}\left(\Delta \mathrm{G}^{\circ}=-426.4 \mathrm{KJ} \mathrm{mol}^{-1}\right) \\
& 3 \mathbf{M g}_{(1)}+\mathbf{F e}_{2} \mathbf{O}_{3(\mathbf{s})} \leftrightarrow 3 \mathbf{M g O}_{(\mathbf{s})}+2 \mathbf{F e}_{(\mathbf{s})}\left(\Delta \mathbf{G}^{\circ}=-917 \mathrm{KJ} \mathrm{mol}^{-1}\right) \\
& \mathbf{M g A l}_{2} \mathbf{O}_{4(\mathbf{s})}+3 \mathbf{M g}_{(\mathbf{l})} \leftrightarrow 4 \mathbf{M g O}_{(\mathrm{s})}+2 \mathrm{Al}_{(\mathrm{s})}\left(\Delta \mathbf{G}^{\circ}=-84.9 \mathrm{KJ} \mathrm{mol}^{-1}\right)
\end{aligned}
$$

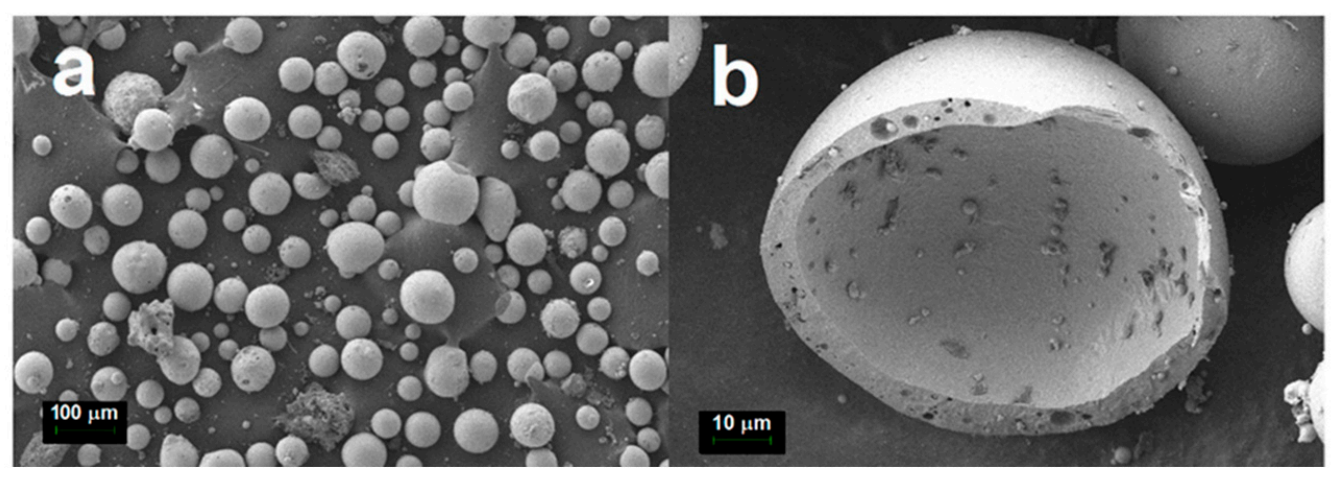

Figure 2. Microstructure of fly ash cenospheres showing (a) general overview and (b) cross section (from open access publication Choo et al. [26]).

\subsection{Fly Ash Reinforced Al Matrix Composites}

Fly ash reinforced $\mathrm{Al}$ composites using ultrasonic vibration assisted stir casting technique was produced by Sharma et al. [27] wherein the addition of $8 \mathrm{wt}$.\% fly-ash particles $(<200 \mu \mathrm{m})$ improved the strength from $52 \mathrm{MPa}$ to $140 \mathrm{MPa}$ and hardness from 34.5 to $48.5 \mathrm{HV}$, respectively (Table 12). While good wettability existed between Al matrix and fly ash particles, beyond $8 \mathrm{wt} \%$, the mechanical properties deteriorated due to the poor distribution or agglomeration of fly ash particles in Al matrix.

Table 12. Effect of $\mathrm{Mg}$ addition on the properties of $\mathrm{Al} / 8 \%$ fly ash composites [27].

\begin{tabular}{cccccc}
\hline \multirow{2}{*}{ Material } & Density & Hardness & Ultimate Strength & Elongation & Toughness \\
\cline { 2 - 6 } & $\mathbf{( g / \mathbf { c m } ^ { \mathbf { 3 } } )}$ & $\mathbf{( V H N )}$ & $\mathbf{( M P a )}$ & $\mathbf{( \% )}$ & $\mathbf{( J )}$ \\
\hline Al-8FA & 2.532 & 48.5 & 140 & 0.43 & 6 \\
Al-8FA-2Mg & 2.49 & 55 & 148 & 0.48 & 4.5 \\
Al-8FA-4Mg & 2.432 & 49.5 & 130 & 0.37 & 4 \\
Al-8FA-6Mg & 2.402 & 44.5 & 120 & 0.43 & 3.5 \\
\hline
\end{tabular}


AA6061 based composites reinforced with different amounts (up to 12 wt.\%) of fly ash particles $(1-2 \mu \mathrm{m})$ were fabricated by compocasting [28]. There was no chemical reaction between fly ash particles and Al melt, and the fly ash reinforced composites showed improved hardness and strength by $120 \%$ and $50 \%$ (Table 13 ) respectively.

Table 13. Properties of fly ash reinforced AA6061 composites [28].

\begin{tabular}{cccc}
\hline $\begin{array}{c}\text { Fly Ash Content } \\
\text { (wt.\%) }\end{array}$ & Hardness & Ultimate Strength & Elongation \\
\cline { 2 - 4 } & $\mathbf{( V H N )}$ & $\mathbf{( M P a )}$ & $\mathbf{( \% )}$ \\
\hline 0 & 50 & 150 & 13.8 \\
4 & 80 & 170 & 11.5 \\
8 & 95 & 210 & 7.2 \\
12 & 118 & 240 & 5 \\
\hline
\end{tabular}

Cenosphere particles of broad size distribution from fly ash were used by Luong et al. [29] to develop A4032 based composites by stir casting. Compressive properties at varying strain rates showed that deformation of composite at high strain rates resulted in damage to the cenosphere particles, which contributed to the additional energy absorption capability and hence strain rate sensitivity for the yield strength. The composite had higher yield strength and elastic energy absorption capabilities than the unreinforced alloy [30].

High volume fraction of up to 65 vol.\% fly ash $\mathrm{ZrO}_{2}$ coated cenosphere particles of different size were reinforced in A356 alloy using pressure infiltration of Al-melt by nitrogen gas [31]. Compression yield strength (Table 14) decreased with the increase in cenosphere content due to the poor strength of cenosphere particles. Composites with bigger particles contributed to higher yield strength and the variation in strength is due to the void content between the particles that affects the infiltration efficiency.

Table 14. Effect of fly ash particle size on the yield strength and Young's Modulus of A356 composites [31].

\begin{tabular}{ccc}
\hline $\begin{array}{c}\text { Fly Ash Particle Size } \\
(\boldsymbol{\mu m})\end{array}$ & $\begin{array}{c}\mathbf{0 . 2 \%} \text { Yield Strength } \\
\mathbf{( M P a )}\end{array}$ & $\begin{array}{c}\text { Young's Modulus } \\
\text { (MPa) }\end{array}$ \\
\hline $75-106$ & 9 & 1274 \\
$106-150$ & 17 & 2562 \\
$150-250$ & 34 & 3111 \\
$150-250$ & 25 & 3119 \\
$150-250$ & 30 & 3548 \\
$150-250$ & 49 & 3768 \\
$150-250$ & 64 & 3826 \\
$150-250$ & 73 & 4125 \\
$150-250$ & 75 & 4355 \\
\hline
\end{tabular}

Juang et al. [32] also studied the properties of the effect of multi-process on Al matrix composites reinforced with cenosphere particles, wherein stir cast composites were further friction stir processed. The friction stir process, induced a particle size reduction from a size range of $53-106 \mu \mathrm{m}$ to $<10 \mu \mathrm{m}$ and facilitated uniform distribution of the particles in Al-matrix. Increase in \% elongation of the resulting composite is a major advantage of multi-processing (Table 15).

Al2024 alloy-based hybrid composites with combined addition of SiC and fly ash particles were developed by stir casting [33]. Hybrid reinforcement addition improved tensile strength and hardness, but reduced elongation due to poor wettability (Table 16). However, in cast A535 alloy composites reinforced with a mixture of SiC and fly ash particles, a reduction in tensile and impact strengths occurred when the amount of fly ash particles (1-100 $\mu \mathrm{m}$ ) was increased (Table 17) [34]. The reduced solid solution strengthening effect by the alloying element $\mathrm{Mg}$, and the reduction in wettability of the reinforcement due to low $\mathrm{Mg}$ content caused the strength reduction [35]. 
Table 15. Effect of fly ash cenosphere content and friction stir processing on the properties of $\mathrm{Al}$ composites [32].

${ }^{*}$ MP-FSP: multi-processing friction stir processing.

Table 16. Properties of SiC and FA reinforced Al-1.5Mg alloy composites [33].

\begin{tabular}{cccccc}
\hline Material & Density & Hardness & Tensile Strength & Yield Strength & Elongation \\
\hline & $\mathbf{( g / \mathbf { c m } ^ { 3 } )}$ & $\mathbf{( B H N )}$ & $\mathbf{( M P a )}$ & $\mathbf{( M P a )}$ & $\mathbf{( \% )}$ \\
\hline Al-1.5Mg & 2.6 & 79.9 & 236 & 220 & 19.4 \\
Al-1.5Mg-5SiC & 2.47 & 85.3 & 248 & 236 & 19 \\
Al-1.5Mg-10SiC & 2.31 & 87.2 & 265 & 257 & 18.2 \\
Al-1.5Mg-5FA & 2.44 & 80.6 & 245 & 233 & 16.3 \\
Al-1.5Mg-10FA & 2.27 & 83.8 & 263 & 252 & 15.8 \\
Al-1.5Mg-5SiC-5FA & 2.2 & & 276 & 269 & 14.4 \\
Al-1.5Mg-5SiC-10FA & 2.13 & & 278 & 275 & 13.8 \\
Al-1.5Mg-10SiC-5FA & 2.12 & & 285 & 287 & 12.8 \\
Al-1.5Mg-10SiC-10FA & 2.06 & & 293 & & 11.9 \\
\hline
\end{tabular}

Table 17. Properties of SiC and FA reinforced A535 alloy composites in as-cast (AC) and heat treated (HT) conditions [34].

\begin{tabular}{ccccccccc}
\hline \multirow{2}{*}{ Material } & \multicolumn{2}{c}{ Hardness } & \multicolumn{2}{c}{$\begin{array}{c}\text { Tensile } \\
\text { Strength }\end{array}$} & \multicolumn{2}{c}{ Elongation } & \multicolumn{2}{c}{ Impact Energy } \\
\cline { 2 - 9 } & \multicolumn{2}{c}{$\mathbf{( V H N )}$} & \multicolumn{2}{c}{$\mathbf{( M P a )}$} & \multicolumn{2}{c}{$\mathbf{( \% )}$} & \multicolumn{2}{c}{$\mathbf{( J )}$} \\
\cline { 2 - 10 } & AC & HT & AC & HT & AC & HT & AC & HT \\
\hline A535 & 170 & 175 & 240 & 220 & 9.8 & 9.8 & 13.5 & - \\
A535-5FA-5SiC & 140 & 150 & 130 & 130 & 4.0 & 3.8 & 4.0 & - \\
A535-10FA & 120 & 130 & 80 & 80 & 3.0 & 3.0 & 2.2 & - \\
A535-15FA & 105 & 110 & 40 & 70 & 2.4 & 2.4 & - & - \\
\hline
\end{tabular}

Tribological behavior of $(10 \mu \mathrm{m})$ fly ash particle reinforced Al12.2Si alloy-based composites fabricated by stir casting method showed reduced coefficient of friction and wear rates due to reinforcement particles [36]. Abrasion and oxidation wear were identified as major wear mechanisms. Wear by delamination observed for lower reinforcement content changed to thermal softening and adhesion at higher sliding velocity. Higher fly ash content (i) reduced delamination and adhesive wear and (ii) reduced corrosion resistance.

The dry sliding wear behavior of stir cast AlSi10Mg alloy-based composites reinforced with graphite and fly ash particles $(53-75 \mu \mathrm{m})$ were studied using different loads and constant sliding speed $(2 \mathrm{~m} / \mathrm{s})$ and distance $(2400 \mathrm{~m})$ [37]. Addition of graphite particles reduced the coefficient of friction and wear rate, which reduced further with fly ash addition. Abrasive wear and delamination were dominant wear mechanisms at lower loads, while adhesive wear was observed at larger loads.

Microstructure and corrosion behavior of fly ash $(<250 \mu \mathrm{m})$ reinforced AK12 composites fabricated by gravity and squeeze casting method showed (i) uniform distribution of fly ash particles, (ii) good interfacial bonding (iii) minimum porosity, (iv) interfacial reaction products and (v) increased pitting corrosion due to the presence of nobler phases 
in fly ash particles [38]. Similar results were reported by Rao et al. [39] in fly ash reinforced AA2024 composites. The increased pitting corrosion was due to the discontinuous passive oxide layer on the surface of composites, over the fly ash particles and intermetallics.

\subsection{Fly Ash Reinforced Mg Matrix Composites}

Syntactic composite foams based on magnesium matrix and hollow fly ash cenosphere particles $(\sim 50 \mu \mathrm{m})$ were synthesized using powder metallurgy technique involving hybrid microwave sintering, with varying cenosphere volume fraction [40]. While a maximum reduction in density by $18 \%$ was reported for the composite with $15 \%$ cenosphere, microstructure showed distribution of fine $\mathrm{MgO}, \mathrm{Mg}_{2} \mathrm{Si}$ intermetallics together with intact and few broken cenosphere with good interfacial integrity. Specific tensile strength was retained with a marginal reduction in ductility (Table 18). Cenosphere reinforced Mg composites fabricated by DMD technique also showed similar characteristics [41].

Table 18. Properties of cenosphere reinforced Mg composites processed by DMD and PM methods [40,41].

\begin{tabular}{|c|c|c|c|c|c|c|c|c|}
\hline \multirow{3}{*}{ Material } & \multirow[b]{2}{*}{ Density } & \multirow[b]{2}{*}{ Microhardness } & \multicolumn{3}{|c|}{ Tensile Properties } & \multicolumn{3}{|c|}{ Compressive Properties } \\
\hline & & & $\begin{array}{c}\text { Yield } \\
\text { Strength }\end{array}$ & $\begin{array}{l}\text { Tensile } \\
\text { Strength }\end{array}$ & $\begin{array}{l}\text { Failure } \\
\text { Strain }\end{array}$ & $\begin{array}{c}\text { Yield } \\
\text { Strength }\end{array}$ & $\begin{array}{l}\text { Tensile } \\
\text { Strength }\end{array}$ & $\begin{array}{l}\text { Failure } \\
\text { Strain }\end{array}$ \\
\hline & $\left(\mathrm{g} / \mathrm{cm}^{3}\right)$ & (VHN) & (MPa) & (MPa) & $(\%)$ & (MPa) & (MPa) & $(\%)$ \\
\hline \multicolumn{9}{|c|}{ Processed by hybrid microwave sintering assisted powder metallurgy (PM) method } \\
\hline $\mathrm{Mg}$ & 1.74 & $47 \pm 2$ & $115 \pm 5$ & $170 \pm 8$ & $6.5 \pm 1.1$ & $70 \pm 4$ & $180 \pm 9$ & $16 \pm 1$ \\
\hline Mg-5Ceno & 1.64 & $98 \pm 2$ & $180 \pm 7$ & $230 \pm 10$ & $5.1 \pm 0.9$ & $100 \pm 9$ & $330 \pm 7$ & $22 \pm 1.5$ \\
\hline Mg-10Ceno & 1.49 & $110 \pm 6$ & $150 \pm 8$ & $215 \pm 9$ & $3.1 \pm 1.0$ & $130 \pm 12$ & $350 \pm 6$ & $22.5 \pm 2$ \\
\hline Mg-15Ceno & 1.42 & $112 \pm 7$ & $130 \pm 7$ & $180 \pm 8$ & $1.5 \pm 0.9$ & $150 \pm 4$ & $370 \pm 6$ & $23 \pm 2$ \\
\hline \multicolumn{9}{|c|}{ Processed by disintegrated melt deposition (DMD) method } \\
\hline $\mathrm{Mg}$ & 1.74 & $49 \pm 4$ & $96 \pm 8$ & $148 \pm 10$ & $5.9 \pm 1.3$ & $52 \pm 8$ & $245 \pm 8$ & $16.8 \pm 0.9$ \\
\hline Mg-5Ceno & 1.59 & $61 \pm 3$ & $107 \pm 7$ & $158 \pm 11$ & $4.4 \pm 0.6$ & $64 \pm 3$ & $218 \pm 4$ & $18.8 \pm 0.4$ \\
\hline Mg-10Ceno & 1.47 & $66 \pm 1$ & $95 \pm 9$ & $148 \pm 13$ & $4.7 \pm 05$ & $61 \pm 6$ & $226 \pm 11$ & $21.2 \pm 1.2$ \\
\hline Mg-15Ceno & 1.42 & $54 \pm 2$ & $88 \pm 12$ & $137 \pm 17$ & $4.1 \pm 0.2$ & $46 \pm 7$ & $221 \pm 7$ & $18.7 \pm 0.4$ \\
\hline
\end{tabular}

Corrosion behavior of powder metallurgy processed AZ61 alloy based composites reinforced with fly ash microspheres $(100-250 \mu \mathrm{m})$ was tested in $3 \mathrm{wt}$.\% sodium chloride solution and the results revealed better corrosion resistance in composites (Table 19) due to minimal galvanic interaction and reduced surface area of the material exposed to the corrosion medium [42].

Up to $10 \mathrm{wt} . \%$ fly ash cenosphere particles $(\sim 148 \mu \mathrm{m})$ were used to produce degradable AZ91 based Mg alloy composites by stir casting [43]. Grain refinement occurred due to the presence of $\beta-\mathrm{Mg}_{17} \mathrm{Al}_{12}, \mathrm{Mg}_{2} \mathrm{Si}$ and $\mathrm{MgO}$ phases together with fly ash cenosphere particles. Compressive strength increased up to $375 \mathrm{MPa}$ due to grain refinement and presence of $\mathrm{Mg}_{2} \mathrm{Si}$ phases. Corrosion behavior in $3 \mathrm{wt} . \%$ potassium chloride solution at $80{ }^{\circ} \mathrm{C}$ showed the highest corrosion rate value of $5 \mathrm{~g} / \mathrm{h}$ for $10 \%$ cenosphere composite. The increased corrosion rate of the composites by more than 3 times when compared to the unreinforced alloy was attributed to the micro-galvanic corrosion effects due to cenosphere and $\mathrm{Mg}_{2} \mathrm{Si}$ phases.

Nickel coating on fly ash cenospheres $(63-125 \mu \mathrm{m})$ and the processibility of AZ91/ cenosphere composites produced by negative pressure infiltration showed $\mathrm{Al}_{3} \mathrm{Ni}_{2}$ and $\mathrm{Mg}_{2} \mathrm{Ni}$ intermetallic phases at particle matrix interface [44]. The effect of heat treatment of nickel coated cenospheres powder prior to the infiltration process indicated the formation of fine $\mathrm{NiO}$ layer outside the coated powder surface. This layer remained stable during processing and prevented the reaction between cenosphere walls and the matrix alloy and contributed to intact cenospheres (Figure 3). 
Table 19. Density and corrosion properties of AZ61 alloy based composites reinforced with fly ash microspheres [42].

\begin{tabular}{ccccc}
\hline \multirow{2}{*}{ Sample } & Density & $\mathbf{E}_{\text {corr }}$ & $\mathbf{i}_{\text {corr }}$ & Corrosion Rate \\
\cline { 2 - 5 } & $\mathbf{( g / \mathbf { c m } ^ { 3 } )}$ & $\mathbf{( m V )}$ & $\left(\mu \mathbf{A} / \mathbf{c m}^{\mathbf{2}}\right)$ & $(\mathbf{m m} /$ year) \\
\hline AZ61 & $1.58 \pm 0.03$ & -1462.04 & 2.86 & 0.071 \\
AZ61/20\% FA & $1.21 \pm 0.01$ & -1478.82 & 2.79 & 0.090 \\
AZ61/30\% FA & $1.30 \pm 0.03$ & -1412.60 & 1.83 & 0.055 \\
AZ61/40\% FA & $1.26 \pm 0.04$ & -1171.76 & 0.48 & 0.015 \\
\hline
\end{tabular}

Processing

(a)
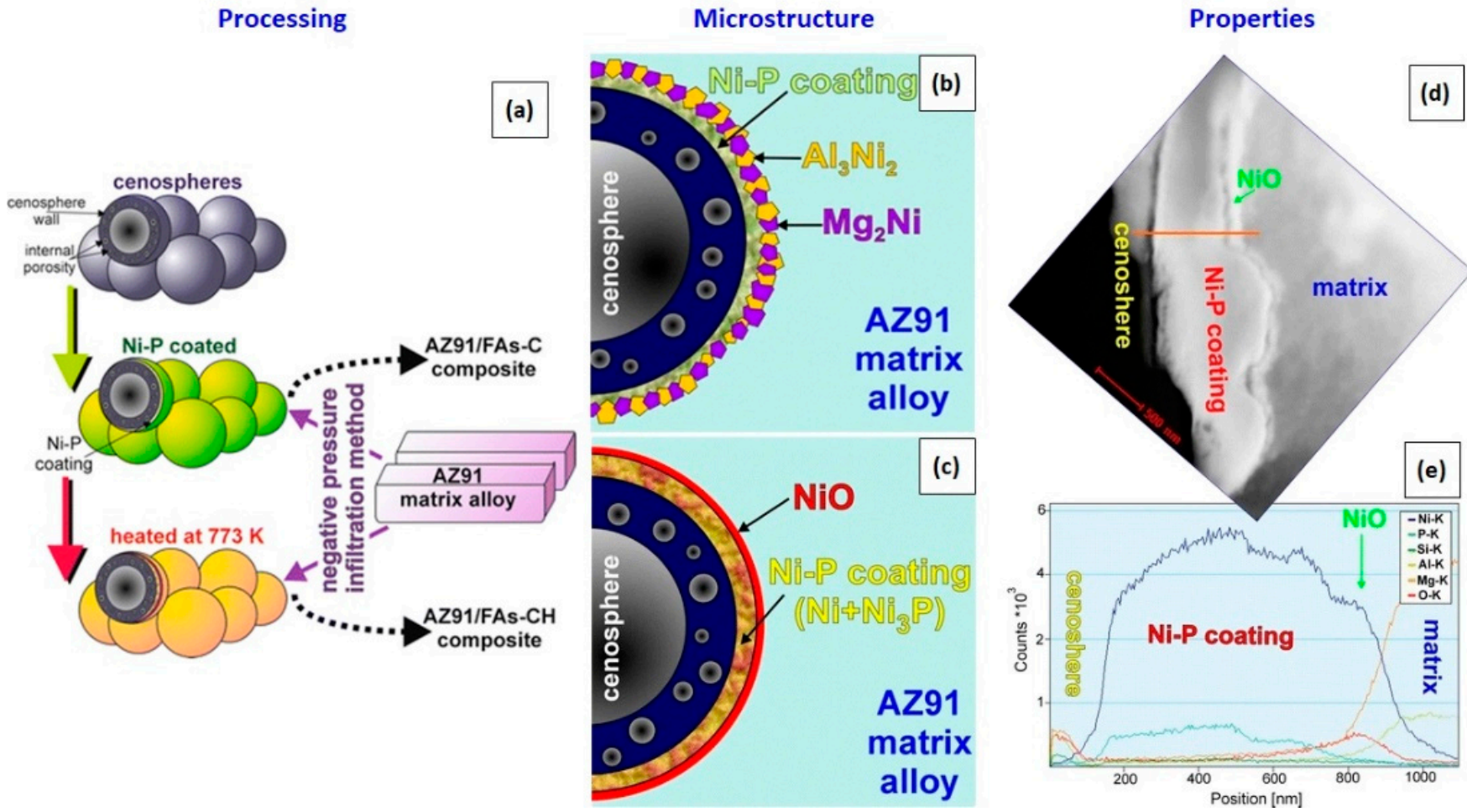

Figure 3. Overview of (a) processing, (b,c) microstructural configuration (highlighting different interfacial reaction products) and (d,e) interfacial properties (composition distribution) of Ni coated cenosphere reinforced AZ91 alloy composites (From open access article [44]).

\section{Rice Husk Ash Reinforced Metal Matrix Composites}

Rice husk ash is an agricultural waste by-product which contains about 90-98 silica after combustion. Singh and Singh [45] reported the chemical composition of rice husk ash before and after treatment as shown in Table 20. Hard ceramic phases like $\mathrm{Al}_{2} \mathrm{O}_{3}, \mathrm{CaO}$, $\mathrm{Fe}_{2} \mathrm{O}_{3}, \mathrm{~K} 2 \mathrm{O}, \mathrm{MgO}$ and $\mathrm{Na}_{2} \mathrm{O}$ were present in addition to $\mathrm{SiO}_{2}$ in both treated and untreated conditions. Therefore, the potential of rice husk ash as eco-friendly reinforcement was explored by different researchers.

Table 20. Chemical composition of rice husk ash [45].

\begin{tabular}{cccccccc}
\hline Compounds & $\mathbf{A l}_{\mathbf{2}} \mathbf{O}_{\mathbf{3}}$ & $\mathbf{C a O}$ & $\mathbf{F e}_{\mathbf{2}} \mathbf{O}_{\mathbf{3}}$ & $\mathbf{K}_{\mathbf{2}} \mathbf{O}$ & $\mathbf{M g O}$ & $\mathbf{N a}_{\mathbf{2}} \mathbf{O}$ & $\mathbf{S i O}_{\mathbf{2}}$ \\
\hline Before treatment & 4.1 & 0.34 & 0.64 & 2.15 & 0.64 & 0.15 & 91.6 \\
After treatment & 3.06 & 0.56 & 0.15 & 2.67 & 0.73 & 0.36 & 91.6 \\
\hline
\end{tabular}

AlSi10Mg based composites reinforced with rice husk ash particles (50-150 $\mu \mathrm{m})$ were produced by melt processing method [46]. The composites showed higher strength due to uniform distribution of reinforcement. Stir cast AlSi10Mg alloy-based composites reinforced 
with rice husk particles were subjected to artificial aging at different temperatures between 135 and $225^{\circ} \mathrm{C}$ and tested for hardness and wear [47]. At peak aging condition $\left(175^{\circ} \mathrm{C}\right)$, the formation of coherent precipitates improved the hardness of alloy and composite by $26.71 \%$ and $53.12 \%$ respectively (Figure 4 ). Although the wear rates of both alloy and composite increased with increasing load in both as cast and heat-treated conditions, the composites exhibited less material loss compared to the alloy due to the load bearing capabilities of rice husk ash particle reinforcement (Figure 4). Similarly, the material loss in heat treated condition was significantly less when compared to the as-cast state due to the fragmentation of plate shaped eutectic $\mathrm{Si}$ in as-cast condition to spherical particles upon heat treatment (Figure 4).
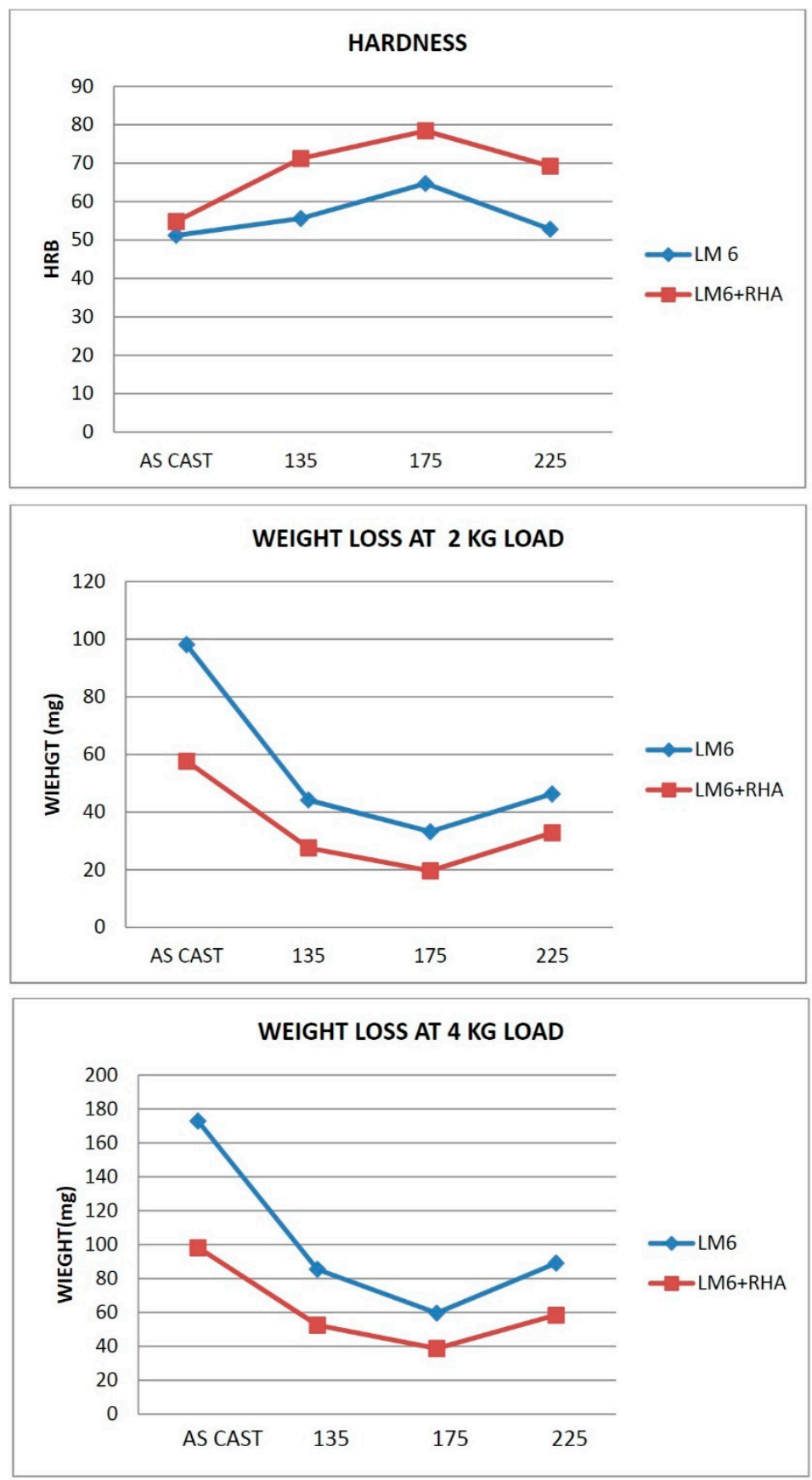

Figure 4. Properties of rice husk ash reinforced Al composites (From Mishra et al. [47] (C) Elsevier, Rights obtained). 
Studies on the corrosion and tribological properties of rice husk ash and $\mathrm{Al}_{2} \mathrm{O}_{3}$ reinforced Al-Mg-Si alloy matrix composite produced by stir casting showed a drop in corrosion resistance upon the addition of irregular shaped rice husk ash particles [48]. The increase in corrosion rate was proportional to the amount of rice husk ash addition was due to increase in matrix/reinforcement interfacial area resulting in aggravated galvanic corrosion increase. Wear rate increased with increasing amounts of rice husk ash reinforcement, wherein wear mechanism changed from abrasion wear to a combination of both adhesive and abrasive wear.

Compo-cast AA6061 alloy based composites reinforced with rice husk ash particles showed that due to (i) uniform distribution (ii) good interfacial bonding and (iii) absence of interfacial reaction products, the addition of up to $8 \%$ rice husk ash particles $(2-3 \mu \mathrm{m})$ improved the strength and hardness [49]. In another study, the use of $\mathrm{Mg}(1 \%)$ as a wetting agent ensured good interfacial bonding between the rice husk ash particle $(105-420 \mu \mathrm{m})$ reinforcement and Al-matrix, along with uniform distribution, resulting in increased hardness and strength of the composite (Table 21) [50].

Table 21. Properties of rice husk ash (RHA) reinforced pure Al and AA6061 alloy based composites [50].

\begin{tabular}{ccccc}
\hline \multirow{2}{*}{ Material } & Density & Hardness & Yield Strength & Ultimate Strength \\
\cline { 2 - 5 } & $\mathbf{( g / \mathbf { c m } ^ { 3 }}$ & $\mathbf{( B H N )}$ & $\mathbf{( M P a )}$ & $\mathbf{( M P a )}$ \\
\hline Al & 2.66 & 22.54 & 47.5 & 91 \\
Al-3RHA & 2.52 & 24.68 & 52 & 96 \\
Al-6RHA & 2.50 & 29.77 & 58 & 113 \\
Al-9RHA & 2.47 & 33.6 & 61 & 115 \\
\hline
\end{tabular}

The properties of stir cast Al-Mg-Si matrix composites reinforced with (2 to $6 \mathrm{wt}$ \%) rice husk ash particles and $10 \mathrm{wt} . \% \mathrm{Al}_{2} \mathrm{O}_{3}(28 \mu \mathrm{m})$ hybrid reinforcement showed a slight decrease in hardness and strength compared to the composite reinforced with only $\mathrm{Al}_{2} \mathrm{O}_{3}$ particles due to the relatively lower hardness of silica present in the rice husk ash [51]. The strength properties of stir cast $\mathrm{Al}$ composites reinforced with rice husk ash $(25 \mu \mathrm{m})$ and SiC $(35 \mu \mathrm{m})$ particles showed an increase in strength properties, with a reduction in ductility (Table 22) [52]. Deshmukh and Pathak [53] explored the utilization of amorphous $\mathrm{SiO}_{2}$ particles (size 32-56 nm) extracted from rice husk ash as a reinforcement in Al-MMC. The composites containing up to $10 \%$ nano- $\mathrm{SiO}_{2}$ from rice husk ask (varying particle size) were produced by stir casting method and the amount of wetting agent $(\mathrm{Mg})$ was varied from $0.5-5 \%$. The addition of $2.5 \mathrm{wt} \% \mathrm{Mg}$ improved the wettability of $\mathrm{SiO}_{2}$ and increased the hardness value due to the formation of hard spinal phases and solid solution. Compared to metallurgical grade, the nano length scale $\mathrm{SiO}_{2}$ derived from rice husk had more surface area and reactivity which resulted in increased porosity. The composite with $2.5 \% \mathrm{Mg}$ showed the lowest wear rate.

Table 22. Properties of RHA and SiC reinforced A356 alloy composites [52].

\begin{tabular}{ccccc}
\hline Sample & Hardness & Yield Strength & Ultimate Strength & \multicolumn{2}{c}{ Elongation } \\
\hline & (BHN) & $\mathbf{( M P a )}$ & $\mathbf{( M P a )}$ & $\mathbf{( \% )}$ \\
\hline A356.2 alloy & 68 & 168 & 263 & 7.35 \\
A356.2/2\%RHA/2\%SiC & 74 & 182 & 296 & 6.25 \\
A356.2/4\%RHA/4\%SiC & 83 & 196 & 310 & 5.6 \\
A356.2/6\%RHA/6\%SiC & 96 & 230 & 333 & 5.15 \\
A356.2/8\%RHA/8\%SiC & 104 & 258 & 356 & 4.9 \\
\hline
\end{tabular}




\section{Coconut Shell/Bamboo Leaf/Sugarcane Ash Reinforced Metal Matrix Composites}

Chemical composition of coconut shell ash is predominantly composed of silicon oxide $\left(\mathrm{SiO}_{2}\right)$ followed by $\mathrm{Al}_{2} \mathrm{O}_{3}, \mathrm{MgO}$ and $\mathrm{Fe}_{2} \mathrm{O}_{3}$ as shown in Table 23. The presence of hard phases combined with its low-density of $2.05 \mathrm{~g} / \mathrm{cc}$ and excellent thermal stability up to $1500{ }^{\circ} \mathrm{C}$ makes coconut shell ash an excellent choice for reinforcement in MMC [54].

Table 23. Chemical composition of coconut shell ash [54].

\begin{tabular}{cccccccccc}
\hline Element & $\mathrm{Al}_{2} \mathrm{O}_{3}$ & $\mathrm{CaO}$ & $\mathrm{Fe}_{2} \mathrm{O}_{3}$ & $\mathrm{~K}_{2} \mathrm{O}$ & $\mathrm{MgO}$ & $\mathrm{Na}_{2} \mathrm{O}$ & $\mathrm{SiO}_{2}$ & $\mathrm{MnO}$ & $\mathrm{ZnO}$ \\
\hline$\%$ & 15.6 & 0.57 & 12.4 & 0.52 & 16.2 & 0.45 & 45.05 & 0.22 & 0.3 \\
\hline
\end{tabular}

Stir cast $\mathrm{Al}$ based hybrid composites reinforced with varying amounts of coconut shell ash $(50-60 \mu \mathrm{m})$ and $\mathrm{SiC}(40-60 \mu \mathrm{m})$ particles showed density reduction with $10 \mathrm{wt} . \%$ coconut shell ash and $5 \mathrm{wt} . \% \mathrm{SiC}$ reinforcements and increase in hardness and tensile strength [55]. However, the impact energy and toughness reduced. Al 1000 alloy-based composite reinforced with coconut shell ash $(60 \mu \mathrm{m})$ particles produced by compo-casting showed that $15 \mathrm{wt} . \%$ coconut shell ash reinforcement reduced the average density and improved the hardness and strength (Table 24), due to the presence of hard $\mathrm{SiO}_{2}$ and $\mathrm{MgO}$ phases [56].

Table 24. Properties of Al based hybrid composites reinforced with coconut shell ash (CSA) and SiC particles [55].

\begin{tabular}{ccccc}
\hline \multirow{2}{*}{ Material } & Density & Hardness & Ultimate Strength & Impact Energy \\
\cline { 2 - 5 } & $\mathbf{( g / \mathbf { c m } ^ { \mathbf { 3 } }}$ & $\mathbf{( V H N )}$ & $\mathbf{( M P a )}$ & $\mathbf{( J )}$ \\
\hline Al & 2.8 & 37 & 60 & 13 \\
Al-3CSA-5SiC & 2.4 & 40 & 120 & 11.5 \\
Al-5CSA-5SiC & 2.2 & 43 & 122 & 9.5 \\
Al-10CSA-5SiC & 1.8 & 45 & 125 & 8 \\
\hline
\end{tabular}

Ash produced during the incineration of bamboo leaf was also used as a reinforcing phase in Al based metal matrix composites. Alaneme et al. [57-59] reported the composition of bamboo leaf ash as $\mathrm{SiO}_{2}(76.4 \mathrm{wt} \%), \mathrm{Al}_{2} \mathrm{O}_{3}(5.04 \mathrm{wt} \%), \mathrm{MgO}(2.05 \mathrm{wt} \%), \mathrm{K}_{2} \mathrm{O}(5.76 \mathrm{wt} \%)$, $\mathrm{CaO}(6.68 \mathrm{wt} \%)$ and $\mathrm{Fe}_{2} \mathrm{O}_{3}$. In these studies, bamboo leaf ash $(<50 \mu \mathrm{m})$ particles was used together with either $\mathrm{Al}_{2} \mathrm{O}_{3}(28 \mu \mathrm{m})$ or $\mathrm{SiC}(30 \mu \mathrm{m})$ particles to prepare hybrid composites by two-step stir casting. While superior fracture toughness was obtained for all the hybrid composite formulations, the increasing bamboo leaf ash content caused an insignificant drop in hardness and tensile strength $[57,58]$. Under tribological test conditions, the hybrid composites showed wear rates comparable to those reinforced with only $\mathrm{SiC}$ or $\mathrm{Al}_{2} \mathrm{O}_{3}$ particles. Corrosion performance of bamboo leaf ash reinforced hybrid composites in 3.5\% $\mathrm{NaCl}$ showed better corrosion resistance, while the composite reinforced with only $\mathrm{SiC}$ particles had superior corrosion resistance in $0.3 \mathrm{M} \mathrm{H}_{2} \mathrm{SO}_{4}$. Localized corrosion due to $\mathrm{Mg}_{2} \mathrm{Si}$ precipitates was also observed in hybrid composites [59].

Studies on stir cast Al-4.5Cu alloy based MMCs with 2-6\% bamboo leaf ash $(<75 \mu \mathrm{m})$ particles showed an increase in tensile strength and hardness up to $4 \%$ reinforcement addition (Table 25), while the density decreased consistently with the amount of bamboo leaf ash content [60]. The improved mechanical properties were attributed to the homogeneous intragranular distribution of reinforcement with a well bonded clear interface. 
Table 25. Properties of bamboo leaf ash (BLA) reinforced Al-4.5Cu alloy based composites [60].

\begin{tabular}{ccccc}
\hline \multirow{2}{*}{ Material } & Density & Yield Strength & Ultimate Strength & Elongation \\
\cline { 2 - 5 } & $\mathbf{( g / \mathbf { c m } ^ { 3 } )}$ & $\mathbf{( M P a )}$ & $\mathbf{( M P a )}$ & $\mathbf{( \% )}$ \\
\hline Al-4.5Cu & 2.75 & 119 & 151 & 3.46 \\
Al-4.5Cu-2BLA & 2.71 & 127 & 162 & 3.06 \\
Al-4.5Cu-4BLA & 2.66 & 133 & 177 & 2.8 \\
Al-4.5Cu-6BLA & 2.62 & 131 & 170 & 2.6 \\
\hline
\end{tabular}

The wear behavior of bagasse ash reinforced $\mathrm{Al}-\mathrm{Cu}-\mathrm{Mg}$ composites produced by stir casting were studied [61]. Bagasse refers to the fibrous residue of sugarcane after the crushing and extraction of its juice. It is mainly composed of cellulose, hemicellulose, lignin, ash, and wax which makes it an exceptional raw material for composite fabrications. Tests conducted at loads from 5 to $20 \mathrm{~N}$ and sliding speeds 1.26 to $5.02 \mathrm{~m} / \mathrm{s}$ showed an increase in wear rate with increasing load and sliding speed. At all conditions, the bagasse ash reinforced composite exhibited better wear resistance compared to the unreinforced alloy. Al-Cu-Mg alloy reinforced with $1-4 \mathrm{wt} . \%$ bean pod ash nanoparticles with size $\sim 55 \mathrm{~nm}$, synthesized by double layer feeding and stir casting showed that the nanocomposites had high hardness and tensile strength due to effective interfacial bonding between the nanoparticles and matrix [62].

\section{MMCs Reinforced with Other Agricultural Wastes}

Atuanya et al. [63] investigated the properties of seed hull ash obtained from breadfruit which is an agricultural waste produced in abundance. In this study, the density of breadfruit seed hull ash ( $500 \mathrm{~nm})$ was reported as $1.98 \mathrm{~g} / \mathrm{cc}$ i.e., which is markedly low compared to most synthetic ceramic reinforcement. The results of XRF analysis revealed $\mathrm{MgO}, \mathrm{SiO}_{2}, \mathrm{Al}_{2} \mathrm{O}_{3}, \mathrm{Cr}_{2} \mathrm{O}_{3}$ and $\mathrm{Fe}_{2} \mathrm{O}_{3}$ as the dominant constituents of breadfruit seed hull ash which is similar to other green reinforcements like fly ash and rice husk (Table 26). It was also found to be thermally stable up to $900{ }^{\circ} \mathrm{C}$. Based on these findings, varying amounts as a low-cost reinforcement to fabricate Al-Si-Fe based composites were fabricated by stir casting. With increasing amount of reinforcement, the composites showed grain refinement and strength enhancement.

Table 26. XRF analysis of breadfruit hull ash (from Atuanya et al. [63]).

\begin{tabular}{cccccccccc}
\hline Element & $\mathrm{Al}_{2} \mathrm{O}_{3}$ & $\mathrm{Fe}_{\mathbf{2}} \mathrm{O}_{3}$ & $\mathrm{SiO}_{2}$ & $\mathrm{Cr}_{\mathbf{2}} \mathrm{O}_{3}$ & $\mathbf{M g O}$ & $\mathrm{K}_{\mathbf{2}} \mathbf{O}$ & $\mathrm{Na}_{\mathbf{2}} \mathrm{O}$ & $\mathrm{MnO}$ & $\mathrm{ZnO}$ \\
\hline$\%$ & 35.80 & 30.34 & 15.45 & 5.06 & 1.20 & 0.52 & 0.45 & 0.22 & 0.05 \\
\hline
\end{tabular}

Studies on tribological properties of spark plasma sintered cow horn particle reinforced A356 alloy-based composite showed increased sliding wear resistance with the increasing amount of cow horn particles $(150 \mu \mathrm{m})$ [64]. The reinforcement content was a major contributing factor $(69.56 \%)$, affecting the wear resistance of composite, followed by sliding distance $(13.62 \%)$, speed $(10.15 \%)$ and applied load $(6.48 \%$. The optimum values were: $20 \mathrm{wt} . \%$ (reinforcement content), $10 \mathrm{~N}$ (applied load), $3 \mathrm{~m} / \mathrm{s}$ (sliding velocity) and $2000 \mathrm{~m}$ (sliding distance).

Al-Mg-Si based hybrid composites reinforced with different amounts of $\operatorname{SiC}(\sim 28 \mu \mathrm{m})$ and groundnut shell ash $(<50 \mu \mathrm{m})$ particles by stir casting technique tested for mechanical properties and corrosion showed increased tensile and specific strength with the amount of groundnut shell ash content, and the ductility was largely unaffected [65]. The higher strength was due to the increasing amount of oxide ceramic phases in the groundnut shell ash. The composites containing $6-10 \%$ groundnut shell ash and $\mathrm{SiC}$ in varying amounts were corrosion resistant in $3.5 \% \mathrm{NaCl}$ solution but were susceptible to corrosion in $0.3 \mathrm{M}$ $\mathrm{H}_{2} \mathrm{SO}_{4}$ solution. 
Dried aloe vera powder with a wide range of particle size $(0.1-100 \mu \mathrm{m})$ was also used as a reinforcement in $\mathrm{Al}$ alloy composites produced by stir casting [66]. The properties were also compared to that of composites reinforced with fly ash particles. While the tensile strength of fly ash reinforced composite was increased by $30 \%$ compared to pure $\mathrm{Al}$, the composite reinforced with aloe vera powder exhibited an increment by $55.62 \%$. Similarly, the Brinell hardness number of composite reinforced with aloe vera powder was significantly high (33.8) compared to pure $\mathrm{Al}$ (19.0) and fly ash reinforced composite (28.2) (Table 27). The improvement in mechanical properties were attributed to the good dispersibility of aloe vera powder in Al matrix. In a similar study, Omole et al. [67] evaluated the reinforcement capabilities of kernel powder $(\sim 150 \mu \mathrm{m})$ which was prepared by the drying and ball-milling of African walnut kernels, wherein the addition of 3-7 wt.\% walnut powder improved the hardness and tensile properties of Al 6063 alloy.

Table 27. Properties of fly ash and aloe vera particle reinforced Al composites [66].

\begin{tabular}{|c|c|c|c|c|c|}
\hline \multirow{2}{*}{ Material } & Density & Hardness & $\begin{array}{l}\text { Yield } \\
\text { Strength }\end{array}$ & $\begin{array}{l}\text { Ultimate } \\
\text { Strength }\end{array}$ & $\begin{array}{l}\text { Impact } \\
\text { Strength }\end{array}$ \\
\hline & $\left(\mathrm{g} / \mathrm{cm}^{3}\right)$ & (BHN) & (MPa) & (MPa) & $\left(\mathrm{J} / \mathrm{mm}^{2}\right)$ \\
\hline Pure Al & 2.7 & 19 & 10 & 77 & $>0.1$ \\
\hline Al-FA & 2.6 & 28.2 & 53.36 & 104.21 & 1.78 \\
\hline Al-AV & 2.21 & 33.8 & 63 & 119 & 1.8 \\
\hline
\end{tabular}

\section{Eggshell Reinforced Metal Matrix Composites}

Chicken eggshells are waste products that contain more than $95 \% \mathrm{CaCO}_{3}$. Its hard ceramic content combined with lightweight (density-2.8 g/cc) and wider availability makes it an economical and eco-friendly bio-filler reinforcement for making metal matrix composites. The general recovery procedure involves cleaning and drying of outer covering layer followed by ball-milling and carbonization [68].

Dwivedi et al. [69] compared the reinforcement effects of waste eggshells and synthetic $\mathrm{CaCO}_{3}$ particles $(\sim 25 \mu \mathrm{m})$ in AA2014 matrix composites produced by electromagnetic stir casting technique. Results clearly highlights that synthetic $\mathrm{CaCO}_{3}$ cannot be used as a reinforcement in $\mathrm{Al}$ alloy matrix due to the lack of wettability. Carbonized eggshells are prospective green reinforcement. The eggshell reinforced composites showed improved hardness and strength while toughness, ductility and corrosion resistance were reduced although they were found to improve upon heat treatment. The composites showed a significant reduction in density and a cost reduction by $3.92 \%$ and $12.5 \%$, respectively due to the addition of $12.5 \mathrm{wt}$.\% carbonized eggshells.

Composites based on Al-Cu-Mg alloy containing 2-12 wt.\% irregular shaped eggshell particles of varying particle size were produced by stir casting method [70]. Here, the retention and uniform distribution of eggshell particles reduced the density by $8 \%$ and improved the tensile strength and hardness by $14 \%$ and $25 \%$ respectively. However, the impact energy was decreased by $\sim 25 \%$. The effects of eggshell reinforcement on the properties of AA2024 based composite developed through in-situ melting route showed that addition of $7 \%$ eggshell powder $(\sim 50 \mu \mathrm{m})$ had the most desirable property benefits in terms of hardness, tensile and compressive strength which were improved by $90 \%, 10 \%$ and $76 \%$ respectively when compared to unreinforced AA2024 alloy [71].

Investigations on the effects of carbonised eggshells on the microstructure, density, and corrosion resistance of AA 1050 alloy produced by stir casting method showed that the addition of 2-8 wt.\% eggshell particles $(5-44 \mu \mathrm{m})$ resulted up to $11 \%$ increase in tensile and compressive strength due to the uniform distribution of reinforcement [72]. The composites showed lower density with increasing amount of low-density eggshell reinforcement (Table 28). Further, corrosion resistance improved in composites with $8 \mathrm{wt} . \%$ eggshell reinforcement addition. 
Table 28. Properties of egg shell (ES) particles reinforced Al1050 alloy composites [72].

\begin{tabular}{ccccccc}
\hline $\begin{array}{c}\text { Egg. Shell } \\
\text { Content } \\
(\mathbf{w t} \mathbf{0})\end{array}$ & Density & Hardness & $\begin{array}{c}\text { Tensile } \\
\text { Strength }\end{array}$ & Elongation & $\begin{array}{c}\text { Compressive } \\
\text { Strength }\end{array}$ & $\begin{array}{c}\text { Corrosion } \\
\text { Rate }\end{array}$ \\
\cline { 2 - 7 } & $\mathbf{( g / \mathbf { c m } ^ { 3 } )}$ & $\mathbf{( V H N )}$ & $\mathbf{( M P a )}$ & $\mathbf{( \% )}$ & $\mathbf{( M P a )}$ & $\mathbf{( \times \mathbf { 1 0 } ^ { - \mathbf { 6 } } \mathbf { g } / \mathbf { h } )}$ \\
\hline 0 & 2.85 & 25.5 & 75 & 19 & 118 & 2.86 \\
2 & 2.56 & 25.6 & 84 & 8.5 & 121 & 6.86 \\
4 & 2.63 & 26.0 & 83 & 9.6 & 121 & 6.05 \\
6 & 2.44 & 27.6 & 76 & 8 & 80 & 9.00 \\
8 & 2.44 & 28.8 & 75 & 7.5 & 120 & 2.59 \\
\hline
\end{tabular}

Parande et al. [73] used eggshell particles $(250-400 \mu \mathrm{m})$ in varying amounts $(3,5$ and $7 \mathrm{wt} \%$ ) to develop Mg-2.5Zn based composites using disintegrated melt deposition method. In this study, the addition of eggshell reinforcement refined the grain size and improved the strength and damping properties of $\mathrm{Mg}-2.58 \mathrm{Zn}$ alloy without significantly affecting the density (Table 29). The corrosion performance of Mg-2.25Zn-5ES was benchmarked against commercial metallic implants and biomedical alloys/composites as its corrosion resistance is significantly improved due to the formation of bioactive apatite layer. However, the $\mathrm{Mg}-2.5 \mathrm{Zn}-7 \mathrm{ES}$ showed susceptibility to micro-galvanic corrosion. When the composites were processed using blend-press-sinter based hybrid microwave sintering assisted powder metallurgy technique, the addition of eggshell reinforcement significantly improved the overall compressive response, damping capacity and the ignition temperature $\left(>750{ }^{\circ} \mathrm{C}\right)$ of the Mg-2.5Zn alloy.

Table 29. Mechanical properties of egg shell particles reinforced Mg-2.5Zn alloy composite [73].

\begin{tabular}{cccccc}
\hline \multirow{2}{*}{ Material } & Density & Grain Size & Modulus & $\begin{array}{c}\text { Comp- Yield } \\
\text { Strength }\end{array}$ & $\begin{array}{c}\text { Comp- } \\
\text { Strength }\end{array}$ \\
\cline { 2 - 6 } & $\mathbf{( g / \mathbf { c m } ^ { 3 } )}$ & $\mathbf{( \mu \mathbf { m } )}$ & $\mathbf{( G P a )}$ & $\mathbf{( M P a )}$ & $\mathbf{( M P a )}$ \\
\hline Mg-2.5Zn & $1.858 \pm 0.003$ & $16.7 \pm 1.7$ & $46.12 \pm 0.5$ & $109 \pm 2$ & $465 \pm 10$ \\
$\mathrm{Mg}-2.5 Z n-3 E S$ & $1.881 \pm 0.002$ & $10.2 \pm 2.1$ & $46.89 \pm 0.8$ & $113 \pm 1.5$ & $440 \pm 20$ \\
$\mathrm{Mg}-2.5 Z n-5 E S$ & $1.895 \pm 0.006$ & $7.9 \pm 1.5$ & $47.65 \pm 0.1$ & $116 \pm 2.5$ & $494 \pm 17$ \\
$\mathrm{Mg}-2.5 Z n-7 E S$ & $1.910 \pm 0.01$ & $6.9 \pm 1.5$ & $48.1 \pm 1.2$ & $117 \pm 1.6$ & $525 \pm 7$ \\
\hline
\end{tabular}

\section{Snail Shell Reinforced Metal Matrix Composites}

Discarded bio-shell waste also includes snail shell for which applications are rarely reported. Kolawole et al. [74] explored the feasibility of using calcinated snail shells as low-cost reinforcement in metal matrix composites. Snail shell is composed of hard oxide ceramics like $\mathrm{CaO}, \mathrm{Fe}_{2} \mathrm{O}_{3}, \mathrm{Al}_{2} \mathrm{O}_{3}, \mathrm{Cr}_{2} \mathrm{O}_{3}, \mathrm{SiO}_{2}, \mathrm{MnO}$, and $\mathrm{NiO}$. The significantly low-density value of snail shell $(1.63 \mathrm{~g} / \mathrm{cc})$ combined with high thermal stability (up to $670{ }^{\circ} \mathrm{C}$ ) ensures weight saving potential of snail shell as bio-shell reinforcement to produce thermally resistant MMCs. By stir casting method, Al-Si alloy-based composites with different amounts of calcinated snail shell particles $(100 \mu \mathrm{m})$ were prepared [74]. Uniform distribution of snail shell particles with good wettability and interfacial bonding enhanced tensile strength and hardness of Al by $50 \%$ (Table 30). Fabrication of Al based composite reinforced with $16-48 \mathrm{wt} . \%$ snail shell particles $(200-600 \mu \mathrm{m})$ by stir casting resulted in a tensile strength of $236 \mathrm{MPa}$ and hardness of $48.3 \mathrm{HRF}$ [75]. 
Table 30. Effect of snail shell particle addition on the properties of Al-Si alloy [74].

\begin{tabular}{ccccccc}
\hline $\begin{array}{c}\text { Snail Shell } \\
\text { Particles } \\
\text { (wt.\%) }\end{array}$ & Density & $\begin{array}{c}\text { Hardness } \\
\text { (HV) }\end{array}$ & $\begin{array}{c}\text { Tensile } \\
\text { Strength } \\
\text { (MPa) }\end{array}$ & $\begin{array}{c}\text { Compressive } \\
\text { Strength } \\
(\mathbf{M P a})\end{array}$ & $\begin{array}{c}\text { Strain } \\
\mathbf{( \% )}\end{array}$ & $\begin{array}{c}\text { Impact } \\
\text { Strength } \\
\text { (J) }\end{array}$ \\
\hline 0 & 2.76 & 98 & 155 & 460 & 20 & 73 \\
1.5 & 2.72 & 102 & 205 & 460 & 33 & 85 \\
3 & 2.71 & 108 & 206 & 490 & 32 & 85 \\
4.5 & 2.61 & 112 & 210 & 520 & 32 & 87 \\
6 & 2.61 & 118 & 205 & 545 & 31 & 89 \\
7.5 & 2.60 & 110 & 200 & 540 & 30 & 90 \\
\hline
\end{tabular}

\section{Processing of Sustainable Metal Matrix Composites}

Processing methods applicable for green composites can be grouped into either liquid or solid-state methods. Stir casting or compo-casting is a liquid state processing method which is highly effective to incorporate green reinforcement into metallic matrices [5]. Figure 5 shows the schematic of stir casting process in which the reinforcing phases are mixed into molten matrix metal by means of mechanical or ultrasonic stirring. The composite slurry can be then cast to required shape by conventional casting methods like die casting. As the distribution of reinforcement can be affected by process parameters like stirrer geometry, stirring speed and duration, size of the crucible and melt temperature, the optimisation of the process variables is essential. The use of surface coatings on green reinforcements to minimize the damage to reinforcement and to promote wettability for effective interfacial bonding has also been explored.

(a)

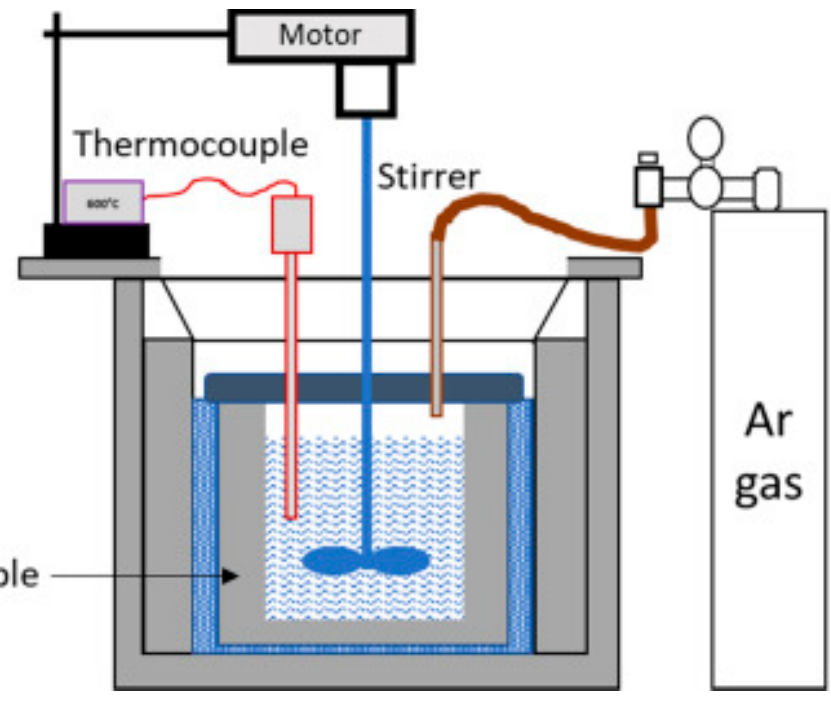

(b) Ultrasonic Stirrer

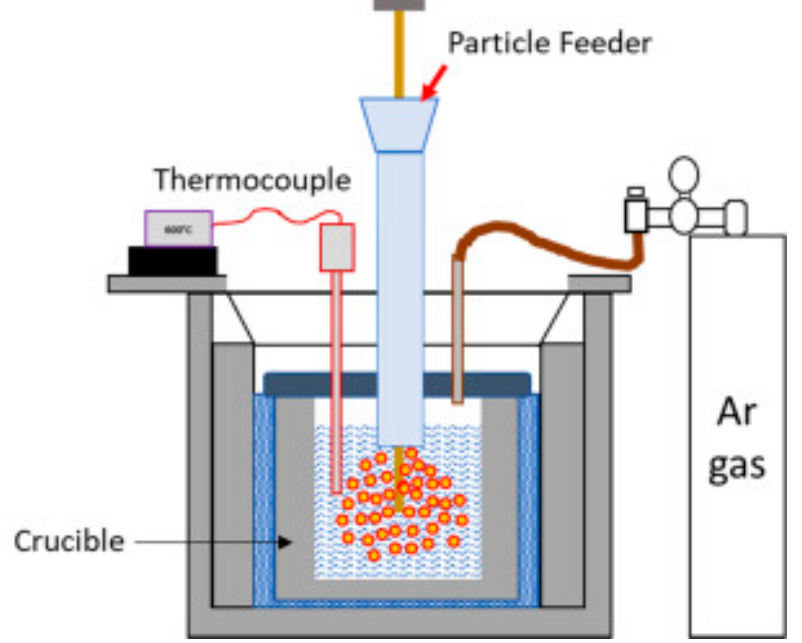

Figure 5. Schematic of (a) mechanical stir casting and (b) ultrasonic stir casting (from Reference [76] (C) Elsevier, Rights obtained).

Melt infiltration is another common method used to incorporate green reinforcement in metal matrix, wherein a liquid metal alloy is either spontaneously (pressure-less infiltration) or force infiltrated into the porous preform of fibers/whiskers reinforcement [76]. Reinforcement volume fraction can be varied up to $70 \%$ depending on the porosity requirements [5]. Pressure-less infiltration is highly suitable for materials like $\mathrm{Al}-\mathrm{Si}, \mathrm{Al}-\mathrm{Mg}$ and $\mathrm{Al}-\mathrm{Zn}$ alloys with better flowability. However, the poor wetting of reinforcements delay the fabrication process and results in undesirable reaction products at the interface. In forced infiltration, an external pressure or mechanical force is used to promote the infiltration of molten metal into the porous reinforcement which helps to overcome issues related to poor wetting and adhesion characteristics. The forced infiltration can be classified as follows: 
- Mechanical Infiltration

- Gas Pressure Infiltration

- Ultrasonic Infiltration

- Vacuum Infiltration and

- Squeeze Casting Infiltration

In mechanical infiltration, the molten metal is forced into the preform by means of plunger movement. The major advantages of this method is its low cost and its capability to produce high precision complex shapes [77]. Gas pressure infiltration on the other hand involves the application of pressurized inert gas either on the melt surface or by first pressing the molten bath into the preform and then infiltrating the bath ${ }^{6}$. Generally, gas pressure is applied in combination with vacuum at the other end of preform to avoid air entrapment.

While the ultrasonic infiltration involves acoustic cavitation effects due to ultrasonic vibrations to infiltrate the molten metal vacuum infiltration makes use of the suction pressure to infiltrate the molten metal through an evacuated preform.

Squeeze casting infiltration process is also a melt processing method that is capable of producing net shape MMCs with green reinforcements [77,78]. Here, the molten metal is first gently forced into the preform and a pressure is applied for densification. The schematic is shown in Figure 6. This method offers greater control over shapes, chemistry, volume fraction and distribution of reinforcement. Since prefabricated fiber or particle preforms can be melt infiltrated and solidified under pressure, this method can be universally applied to both fiber and particle reinforcements. As the solidification occurs under high pressure, the squeeze cast composites are normally free from the common casting defects like porosity and shrinkage cavities. Because of the shorter infiltration time, this method is also suitable for chemically reactive matrix and reinforcement materials. Based on the mode of pressure application, the squeeze casting can be classified into direct and indirect squeeze casting. While direct squeeze casting involves the direct application of pressure onto melt, the melt is pressed into the preform through a gate system in indirect squeeze casting. Therefore, the tooling is relatively simple for direct squeeze casting and it requires accurate determination of the melt volume. On the other hand, the gating system in indirect squeeze casting restricts the movement of oxide residue.
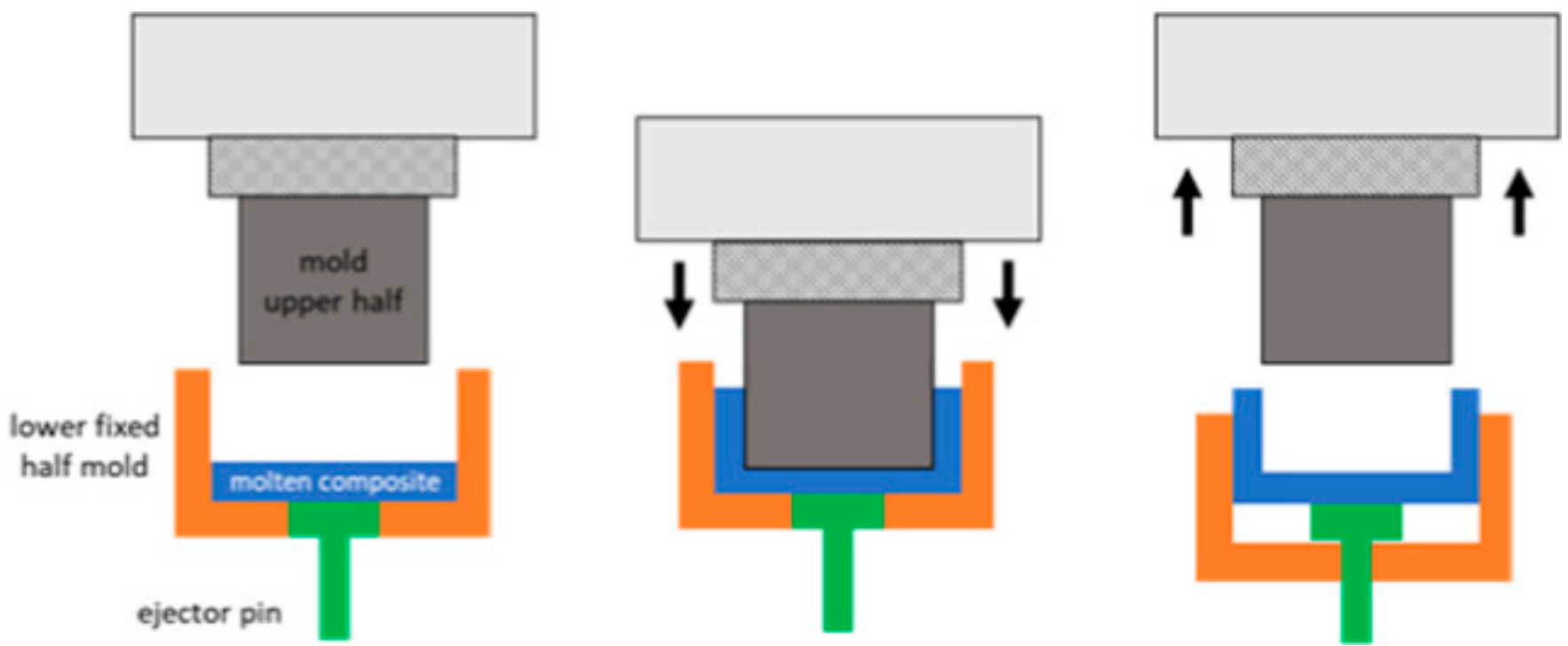

Figure 6. Squeeze Casting (from Reference [76] @ Elsevier, Rights obtained).

Spray and disintegrated melt deposition methods are also being used to produce sustainable metal matrix composites reinforced with green reinforcement $[79,80]$. Figure 7 shows an example of the spray deposition process in which a spray gun is used to atomize 
the molten matrix metal into which the reinforcement particles are injected. The resulting metal matrix composite (about 97\% dense) is then subjected to scalping, consolidation, and secondary finishing processes to produce wrought composites [77,81]. Here, optimum particle size and shape are required to ensure the efficient transfer of particle reinforcement. In case of fiber reinforcements, the molten matrix metal is sprayed onto the fibers with preferred orientation during which the fiber alignment can be easily controlled and a relatively faster solidification rates can be achieved.

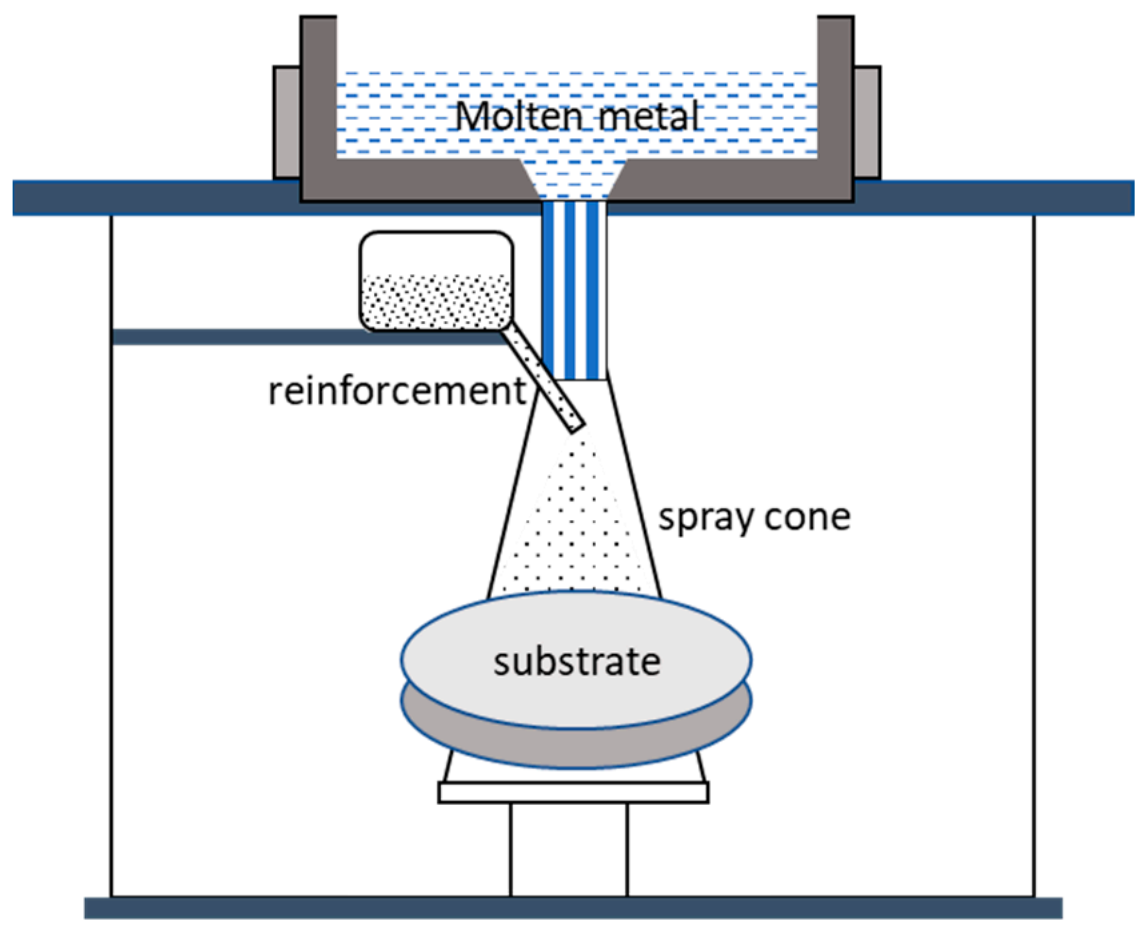

Figure 7. Spray Deposition (from Reference [76] @ Elsevier, Rights obtained).

Disintegrated melt deposition (DMD) combines the advantages of stir casting and spray processing methods (Figure 8 ). Here, the vortex mixing of reinforcements combined with the disintegration of molten slurry by inert gas delivers (i) reduced segregation of reinforcements and (ii) fine grain structure [79].

Solid state powder metallurgy method based on blend-press-sintering was also used to produce metal matrix composites reinforced with green reinforcement [83]. This method involves the preparation of a composite powder blend by mixing the matrix alloy powder with the required amount of green reinforcement as shown in Figure 9. The temperature for sintering is selected closer to the solidus temperature of the matrix alloy which allows atomic diffusion and inter-particle bonding. In most cases, the sintering of green powder compact also facilitates microstructural recrystallization for strengthening alongside densification and removal of residual lubricant. Recent literatures also used domestic and industrial microwave furnaces for the sintering of metal matrix composites although microwave processing has been largely limited to ceramic processing in the past. Unlike conventional heating where the heat is transferred from the surface to the interior by conduction, convection, and radiation, microwave heating happens rapidly from the core to the surface by means of dielectric and magnetic losses resulting from the interaction between the electric and magnetic fields (Figure 10). Therefore, heating by microwaves exhibit an inverse temperature distribution and reduces the processing time substantially by more than $80 \%$. Although powder metallurgy methods are relatively simple for incorporating up to $50 \mathrm{vol} \%$ reinforcement, there are limitations adopting them for complex geometries requiring high dimensional accuracy [84]. 


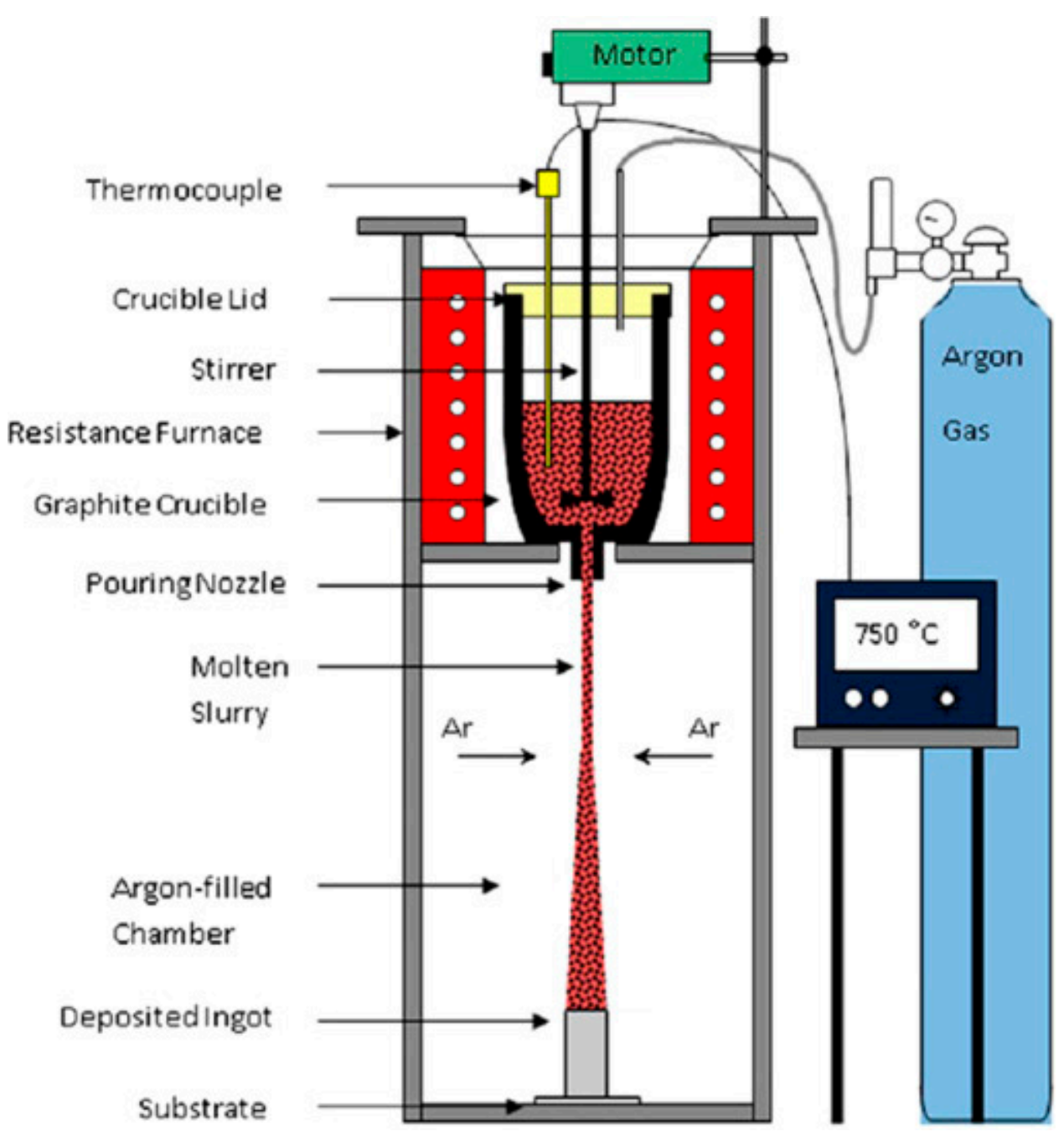

Figure 8. Disintegrated melt deposition (from open access article [82]).

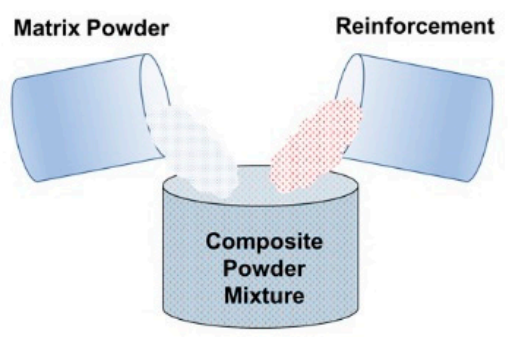

Mixing of Powder Particles

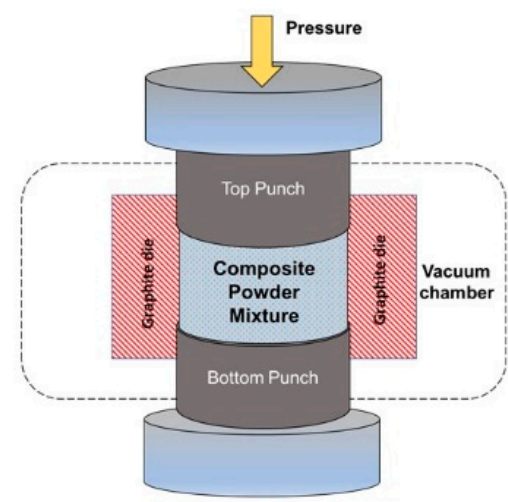

Compaction

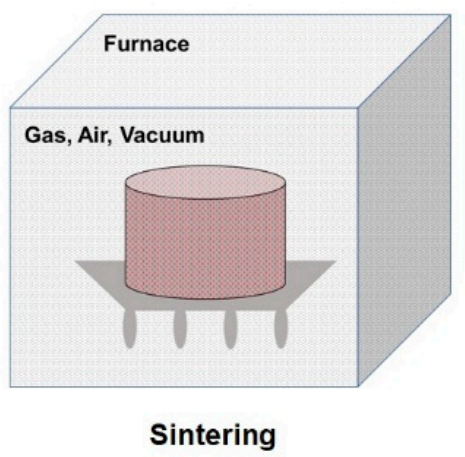

Figure 9. Powder consolidation (from Reference [76] @ Elsevier, Rights obtained). 

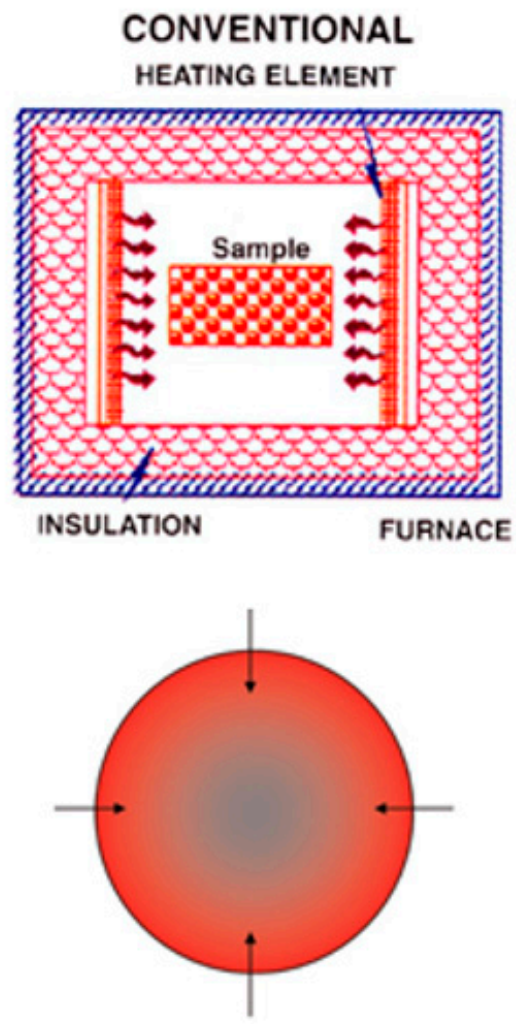

\section{Heat transfer from the surface to the interior}
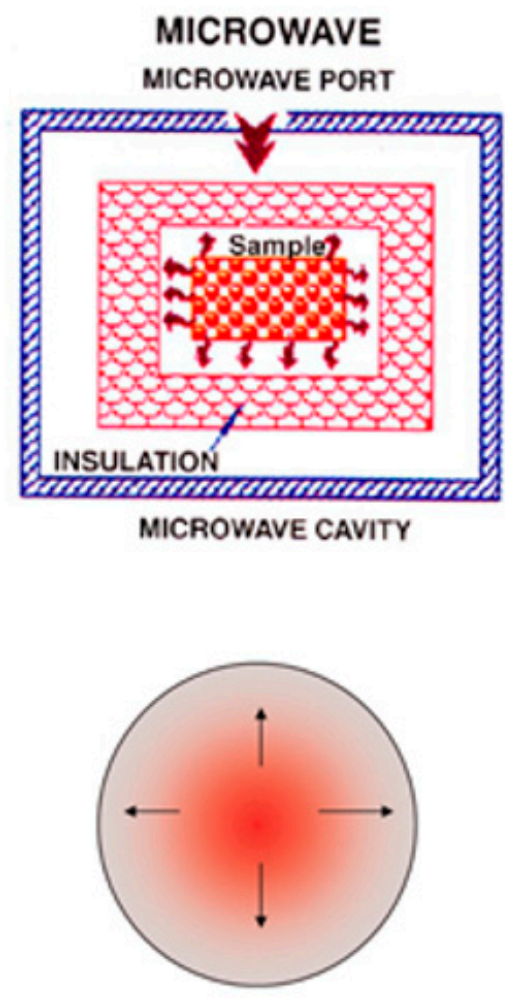

Self heating of the core and heat transfer to the surface

Figure 10. Schematic of hybrid microwave sintering set up and the heat transfer principle compared to conventional heating (from Open access article Penchal et al. [85]).

\section{Outlook}

Similar to synthetic reinforcements, the mineral and industrial wastes such as red mud and fly ash are composed of hard ceramic phases. Several studies have demonstrated their high-value use as sustainable green reinforcement in MMCs, either directly or after refinement and pre-processing $[23,25]$. To this list of green reinforcement based on the recovered waste products, it is also possible to include agricultural and food wastes like the ash from incineration of crop residue, and the powders of natural shell materials like the eggshell and snail shell etc that are rich in calcium compounds.

In general, the utilisation of industrial and mineral/bio-waste helps to address the growing concerns on material sustainability and its impact on environment. As the chemical composition and physical properties of the green reinforcements are comparable to conventional ceramic reinforcement, their addition will invoke multiple strengthening mechanisms to improve the mechanical properties of the matrix material. In general, their addition has improved the mechanical properties of matrix materials. Figure 11 compares the improvement in yield strength of Al based materials due to the addition of sustainable reinforcements.

While the strengthening capabilities of the green reinforcements can be generally attributed to the hard ceramic phases, the influence of impurities in red mud and fly ash on dispersion strengthening was also highlighted $[29,66,86-88]$. However, there are no detailed studies carried out so far exploring the contribution of different strengthening mechanisms in sustainable MMCs reinforced with green reinforcements as the strength prediction becomes cumbersome due to their complex chemical composition. In contrast, some recent studies also highlighted the importance of reducing/eliminating the impurities that are clearly harmful for applications requiring creep and corrosion resistance [88-90]. 


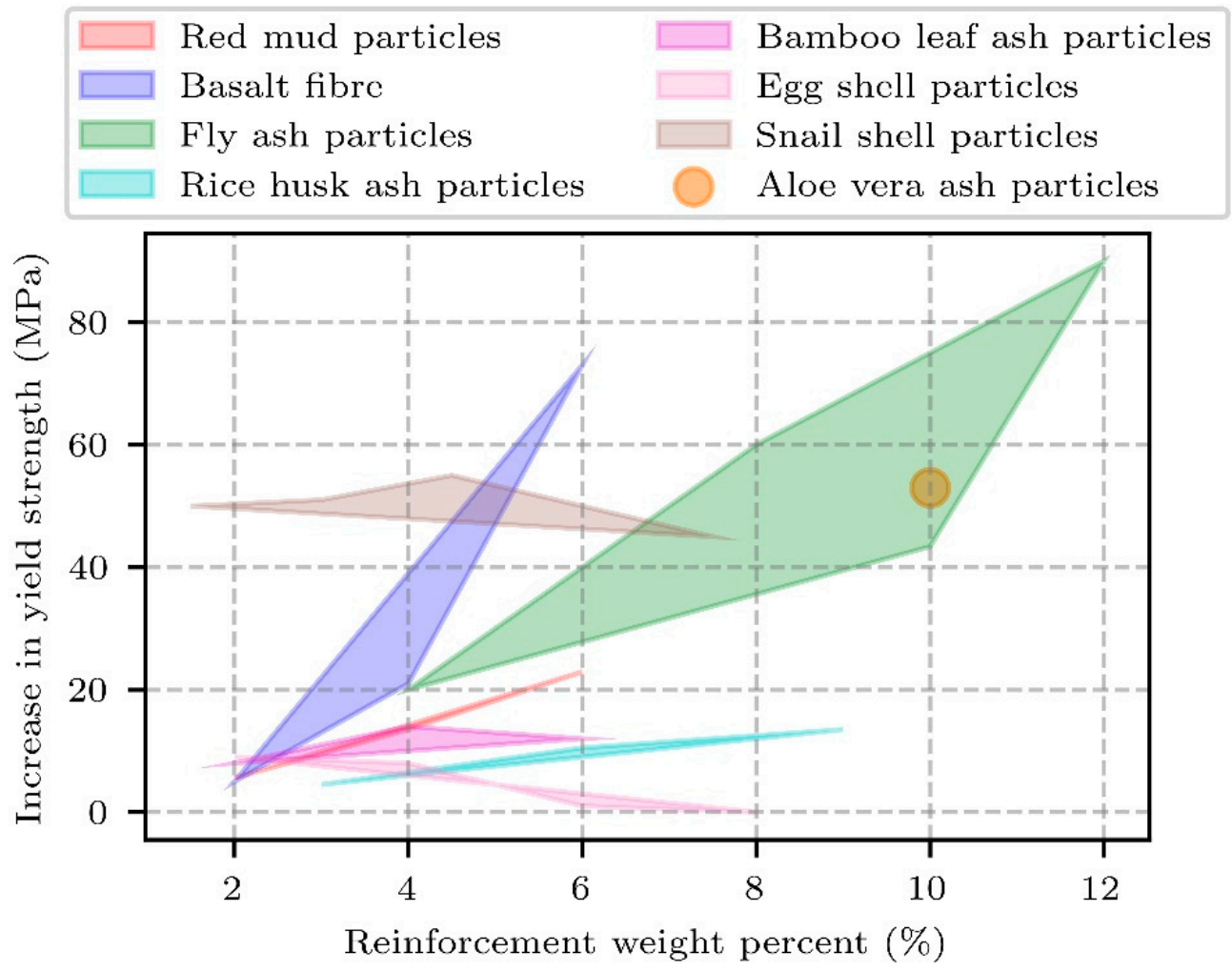

Figure 11. Comparison of strength enhancement in $\mathrm{Al}$-based materials due to different types of reinforcements).

The benefits not only include mechanical property improvement but also helps towards achieving a circular economy with the controlled release of organic and inorganic chemicals due to the decay and combustion of the waste materials. However, the wider adoption of sustainable reinforcement requires further detailed and systematic studies exploring the structure-property relationships, economic assessment, and life cycle analysis. The cost benefit analysis must also include aspects such as the widespread availability, sustainable supply, and process scalability.

In addition, the energy, and cost involved in the preparation of green reinforcements and their properties must also be compared with the traditional and other advanced reinforcements. For example, the conversion of fly ash particles into cenosphere and hollow micro-balloons require several steps such as pulverisation, drying, vacuum separation, and sieving. Similarly, red mud recovery also involves several energy consuming processes for separation, chemical refinement, and screening. Therefore, in life cycle analysis inclusion of each of these steps to understand the actual benefits to environment is essential.

For wider applications, the functional aspects of sustainable MMCs accompanied with a multi-disciplinary approach with design engineers, material scientists, chemists, and innovators need to be explored. For example, the lightweight laptop frame made of bamboo is functionally competent and become so popular as an eco-friendly choice [91]. Similar applications are also possible using sustainable MMCs containing green reinforcements.

\section{Summary}

Green reinforcements based on industrial and agricultural waste materials are being used to develop sustainable metal matrix composites. In general, the choice of green reinforcements is based on: (i) naturally available mineral ore like volcanic rocks, (ii) renewable wastes and by-products from mining and processing industries such as fly ash, red mud, etc., (iii) ash from burning of agricultural waste products like rice husk, sugarcane bagasse, etc., and (iv) the discarded shell materials like eggshells, snail shells etc. Majority of these green reinforcements are composed of significant amounts of ceramic phases like $\mathrm{Al}_{2} \mathrm{O}_{3}$, 
$\mathrm{SiO}_{2}$, and $\mathrm{Fe}_{2} \mathrm{O}_{3}$, and therefore exhibit density lesser or closer to synthetic reinforcements, which are derived from petroleum resources. Currently, these different industrial, agricultural and biowastes materials on their own have not been properly utilized as there exists no real-time applications, except for the utilisation of fly ash in construction and land filling. Further, their proper use requires extensive knowledge generation on these materials. This review article clearly highlights that these materials as green reinforcements present exciting futuristic research opportunities for the development of sustainable metal matrix composites for specific industrial applications.

Author Contributions: Conceptualization, S.S. and M.G.; methodology, S.S.; formal analysis, S.S., J.S. and R.A.S.; investigation, S.S., J.S. and R.A.S.; data curation, S.S. and J.S.; writing-original draft preparation, S.S. and J.S.; writing-review and editing, S.S., J.S., R.A.S., W.L.E.W., M.L.S.N. and M.G. All authors have read and agreed to the published version of the manuscript.

Funding: The authors did not receive any funding for this research work.

Institutional Review Board Statement: Not applicable.

Informed Consent Statement: Not applicable.

Data Availability Statement: It is a review article based on previously published research works.

Conflicts of Interest: The authors declare no conflict of interest.

\section{References}

1. Adebisi, A.A.; Maleque, M.A.; Rahman, M.M. Metal matrix composite brake rotors: Historical development and product life cycle analysis. Int. J. Automot. Mech. Eng. 2011, 4, 471-480. [CrossRef]

2. Callister, W.; Rethwisch, D. Materials Science and Engineering: An Introduction; Wiley: Hoboken, NJ, USA, 2007; Volume 94, ISBN 9780471736967.

3. Ashby, M.F. Materials Selection in Mechanical Design Third Edition. Design 2005, 3, C7-1-C7-9. [CrossRef]

4. Chawla, K.K.; Chawla, N. Metal-Matrix Composites. Mater. Sci. Technol. 2004, 1, 1-25. [CrossRef]

5. Kainer, K.U. Basics of Metal Matrix Composites. In Metal Matrix Composites: Custom-Made Materials for Automotive and Aerospace Engineering; Wiley-VCH: Weinheim, Germany, 2006; ISBN 3527313605.

6. Raabe, D.; Tasan, C.C.; Olivetti, E.A. Strategies for improving the sustainability of structural metals. Nature 2019, 575, 64-74. [CrossRef] [PubMed]

7. Debnath, S.; Lancaster, L.; Lung, M.H. Utilization of agro-industrial waste in metal matrix composites: Towards sustainability. World Acad. Sci. Eng. Technol. 2013, 73, 1136-1144.

8. McConnell, E.E.; Kamstrup, O.; Musselman, R.; Hesterberg, T.W.; Chevalier, J.; Miiller, W.C.; Thevenaz, P. Chronic inhalation study of size-separated rock and slag wool insulation fibers in Fischer 344/N rats. Inhal. Toxicol. 1994, 6, 571-614. [CrossRef]

9. Kogan, F.M.; Nikitina, O.V. Solubility of chrysotile asbestos and basalt fibers in relation to their fibrogenic and carcinogenic action. Environ. Health Perspect. 1994, 102, 205-206.

10. Hao, L.; Yu, W. Evaluation of thermal protective performance of basalt fiber nonwoven fabrics. J. Therm. Anal. Calorim. 2010, 100, 551-555. [CrossRef]

11. Nasir, V.; Karimipour, H.; Taheri-Behrooz, F.; Shokrieh, M.M. Corrosion behaviour and crack formation mechanism of basalt fibre in sulphuric acid. Corros. Sci. 2012, 64, 1-7. [CrossRef]

12. Karthigeyan, R.; Ranganath, G.; Sankaranarayanan, S. Mechanical properties and microstructure studies of aluminium (7075) alloy matrix composite reinforced with short basalt fibre. Eur. J. Sci. Res. 2012, 68, 606-615.

13. Karthigeyan, R.; Ranganath, G. Effect of coating parameters on coating morphology of basal short fiber for preparation of $\mathrm{Al} /$ Basalt Metal matrix composites. Int. J. Sci. Res. 2013, 1, 232-236.

14. Fiore, V.; Di Bella, G.; Valenza, A. Glass-basalt/epoxy hybrid composites for marine applications. Mater. Des. 2011, 32, 2091-2099. [CrossRef]

15. Akhlaghi, F.; Eslami-Farsani, R.; Sabet, S.M.M. Synthesis and characteristics of continuous basalt fiber reinforced aluminum matrix composites. J. Compos. Mater. 2013, 47, 3379-3388. [CrossRef]

16. Sabet, S.M.M.; Akhlaghi, F.; Eslami-Farsani, R. Production and optimization of aluminum-basalt composites by hand lay-out technique. In Proceedings of the World Congress on Engineering, London, UK, 4-6 July 2012; Volume 3, pp. 1826-1829.

17. Vannan, E.; Vizhian, P. Prediction of the elastic properties of short basalt fiber reinforced al alloy metal matrix composites. $J$. Miner. Mater. Charact. Eng. 2014, 2014, 42162. [CrossRef]

18. Chinta, N.D.; Selvaraj, N.; Mahesh, V. Mechanical characterization of aluminium-red mud metal matrix composites. Mater. Today Proc. 2018, 5, 26911-26917. [CrossRef]

19. Harshavardhan, R.; Anil, K.C.; Rao, K.V.S. Evaluation of Fracture Toughness of Red Mud Reinforced Aluminium Matrix Composite. Mater. Today Proc. 2018, 5, 24854-24861. [CrossRef] 
20. Samal, P.; Raj, R.; Mandava, R.K.; Vundavilli, P.R. Effect of red mud on mechanical and microstructural characteristics of aluminum matrix composites. In Advances in Materials and Manufacturing Engineering; Springer: Berlin/Heidelberg, Germany, 2020; pp. 75-82.

21. Samal, P.; Mandava, R.K.; Vundavilli, P.R. Dry sliding wear behavior of Al 6082 metal matrix composites reinforced with red mud particles. SN Appl. Sci. 2020, 2, 313. [CrossRef]

22. Acharya, S.K.; Dikshit, V.; Mishra, P. Erosive wear behaviour of redmud filled metal matrix composite. J. Reinf. Plast. Compos. 2008, 27, 145-152. [CrossRef]

23. Siva Karuna, G.; Swamy, S.; Naidu, G.S. Effect of blast furnace slag and red mud reinforcements on the mechanical properties of aa2024 hybrid composites. In Advanced Materials Research; Trans Tech Publications Ltd.: Bäch SZ, Switzerland, 2018; Volume 1148, pp. 29-36.

24. Kasar, A.K.; Gupta, N.; Rohatgi, P.K.; Menezes, P.L. A brief history of fly ash as reinforcement for composites with improved mechanical and tribological properties. Jom 2020, 72, 2340-2351. [CrossRef]

25. Rohatgi, P.K.; Weiss, D.; Gupta, N. Applications of fly ash in synthesizing low-cost MMCs for automotive and other applications. Jom 2006, 58, 71-76. [CrossRef]

26. Choo, T.F.; Mohd Salleh, M.A.; Kok, K.Y.; Matori, K.A.; Abdul Rashid, S. Effect of temperature on morphology, phase transformations and thermal expansions of coal fly ash cenospheres. Crystals 2020, 10, 481. [CrossRef]

27. Sharma, P.K.; Dwivedi, S.P.; Kumar, A.; Sharma, A.K. Effect of Magnesium Addition on Mechanical Properties of Al-Fly Ash Green Composite Produced Under Green Ultrasonic Vibration Process. Int. J. Precis. Eng. Manuf. Technol. 2019, 6, 559-566. [CrossRef]

28. David Raja Selvam, J.; Robinson Smart, D.S.; Dinaharan, I. Microstructure and some mechanical properties of fly ash particulate reinforced AA6061 aluminum alloy composites prepared by compocasting. Mater. Des. 2013, 49, 28-34. [CrossRef]

29. Luong, D.D.; Gupta, N.; Daoud, A.; Rohatgi, P.K. High strain rate compressive characterization of aluminum alloy/fly ash cenosphere composites. Jom 2011, 63, 53-56. [CrossRef]

30. Rohatgi, P.K.; Gupta, N.; Schultz, B.F.; Luong, D.D. The synthesis, compressive properties, and applications of metal matrix syntactic foams. Jom 2011, 63, 36-42. [CrossRef]

31. Rohatgi, P.K.; Kim, J.K.; Gupta, N.; Alaraj, S.; Daoud, A. Compressive characteristics of A356/fly ash cenosphere composites synthesized by pressure infiltration technique. Compos. Part A Appl. Sci. Manuf. 2006, 37, 430-437. [CrossRef]

32. Juang, S.H.; Xue, C.-S. Investigation of mechanical properties and microstructures of aluminum-fly ash composite processed by friction stirring. Mater. Sci. Eng. A 2015, 640, 314-319. [CrossRef]

33. Boopathi, M.M.; Arulshri, K.P.; Iyandurai, N. Evaluation of Mechanical Properties of Aluminium Alloy 2024 Reinforced with Silicon Carbide and Fly Ash Hybrid Metal Matrix Composites. Am. J. Appl. Sci. 2013, 10, 219. [CrossRef]

34. Gikunoo, E.; Omotoso, O.; Oguocha, I.N.A. Effect of fly ash particles on the mechanical properties of aluminium casting alloy A535. Mater. Sci. Technol. 2005, 21, 143-152. [CrossRef]

35. Hashim, J.; Looney, L.; Hashmi, M.S.J. The wettability of SiC particles by molten aluminium alloy. J. Mater. Process. Technol. 2001, 119, 324-328. [CrossRef]

36. Ramachandra, M.; Radhakrishna, K. Effect of reinforcement of flyash on sliding wear, slurry erosive wear and corrosive behavior of aluminium matrix composite. Wear 2007, 262, 1450-1462. [CrossRef]

37. Venkat Prasat, S.; Subramanian, R. Tribological properties of AlSi10Mg/fly ash/graphite hybrid metal matrix composites. Ind. Lubr. Tribol. 2013, 65, 399-408. [CrossRef]

38. Bienia, J.; Walczak, M.; Surowska, B.; Sobczaka, J. Microstructure and corrosion behaviour of aluminum fly ash composites. J. Optoelectron. Adv. Mater. 2003, 5, 493-502.

39. Rao, J.B.; Rao, D.V.; Murthy, I.N.; Bhargava, N. Mechanical properties and corrosion behaviour of fly ash particles reinforced AA 2024 composites. J. Compos. Mater. 2012, 46, 1393-1404. [CrossRef]

40. Sankaranarayanan, S.; Nguyen, Q.B.; Shabadi, R.; Almajid, A.H.; Gupta, M. Powder metallurgy hollow fly ash cenospheres' particles reinforced magnesium composites. Powder Metall. 2016, 59. [CrossRef]

41. Nguyen, Q.B.; Sharon Nai, M.L.; Nguyen, A.S.; Seetharaman, S.; Wai Leong, E.W.; Gupta, M. Synthesis and properties of light weight magnesium-cenosphere composite. Mater. Sci. Technol. 2016, 32. [CrossRef]

42. Akinwekomi, A.D. Microstructural characterisation and corrosion behaviour of microwave-sintered magnesium alloy AZ61/fly ash microspheres syntactic foams. Heliyon 2019, 5, e01531. [CrossRef]

43. Zhikang, J.; Sirong, Y.; Xiaoli, Y. Degradable Mg alloy composites using fly ash cenospheres. Sci. Eng. Compos. Mater. 2018, 25, 1115-1122. [CrossRef]

44. Braszczyńska-Malik, K.N.; Kamieniak, J. The Role of Ni-P Coating Structure on Fly Ash Cenospheres in the Formation of Magnesium Matrix Composites. Metall. Mater. Trans. A 2017, 48, 5649-5657. [CrossRef]

45. Singh, R.P.; Singh, H. Characterization and comparison of treated and untreated rich hush ash \& fly ash for metal matrix composites. J. Metall. Mater. Sci. 2011, 53, 189-196.

46. Saravanan, S.D.; Senthilkumar, M.; Shankar, S. Effect of Particle Size on Tribological Behavior of Rice Husk Ash-Reinforced Aluminum Alloy (AlSi10Mg) Matrix Composites. Tribol. Trans. 2013, 56, 1156-1167. [CrossRef]

47. Mishra, P.; Mishra, P.; Rana, R.S. Effect of rice husk ash reinforcements on mechanical properties of aluminium alloy (LM6) matrix composites. Mater. Today Proc. 2018, 5, 6018-6022. [CrossRef] 
48. Atuanya, C.U.; Aigbodion, V.S.; Nwigbo, S.C. Characterization of breadfruit seed hull ash for potential utilization in metal matrix composites for automotive application. Peoples J. Sci. Technol. 2012, 2, 2249-5847.

49. Gladston, J.A.K.; Sheriff, N.M.; Dinaharan, I.; Raja Selvam, J.D. Production and characterization of rich husk ash particulate reinforced AA6061 aluminum alloy composites by compocasting. Trans. Nonferrous Met. Soc. China 2015, 25, 683-691. [CrossRef]

50. Ahamed, A.A.; Ahmed, R.; Hossain, M.B.; Billah, M. Fabrication and characterization of aluminium-rice husk ash composite prepared by stir casting method. Rajshahi Univ. J. Sci. Eng. 2016, 44, 9-18. [CrossRef]

51. Alaneme, K.K.; Akintunde, I.B.; Olubambi, P.A.; Adewale, T.M. Fabrication characteristics and mechanical behaviour of rice husk ash-Alumina reinforced Al-Mg-Si alloy matrix hybrid composites. J. Mater. Res. Technol. 2013, 2, 60-67. [CrossRef]

52. Prasad, D.S.; Shoba, C.; Ramanaiah, N. Investigations on mechanical properties of aluminum hybrid composites. J. Mater. Res. Technol. 2014, 3, 79-85. [CrossRef]

53. Deshmukh, P.; Pathak, S. Influence of Varying SiO2 \% on the Mechanical Properties of Al Based MMC. Trans. Indian Inst. Met. 2012, 65, 741-745. [CrossRef]

54. Madakson, P.B.; Yawas, D.S.; Apasi, A. Characterization of coconut shell ash for potential utilization in metal matrix composites for automotive applications. Int. J. Eng. Sci. Technol. 2012, 4, 1190-1198.

55. Poornesh, M.; Saldanha, J.X.; Singh, J.; Gavin Manuel Pinto, G. Effect of coconut shell ash and SiC particles on mechanical properties of aluminium based composites. Am. J. Mater. Sci. 2017, 7, 112-115.

56. Ankesh, K.; Kanhaiya, K.; Suman, S.; Raju, S.S. Study of Physical, Mechanical and Machinability Properties of Aluminium Metal Matrix Composite Reinforced with Coconut Shell Ash particulates. Imp. J. Interdiscip. Res. 2016, 2, 1362.

57. Alaneme, K.K.; Adewuyi, E.O. Mechanical behaviour of Al-Mg-Si matrix composites reinforced with alumina and bamboo leaf ash. Metall. Mater. Eng. 2013, 19, 177-188.

58. Alaneme, K.K.; Babalola, S.A.; Chown, L.H.; Bodunrin, M.O. Hot deformation behaviour of bamboo leaf ash-silicon carbide hybrid reinforced aluminium based composite. Manuf. Rev. 2020, 7, 17. [CrossRef]

59. Alaneme, K.K.; Ademilua, B.O.; Bodunrin, M.O. Mechanical properties and corrosion behaviour of aluminium hybrid composites reinforced with silicon carbide and bamboo leaf ash. Tribol. Ind. 2013, 35, 25.

60. Kumar, B.P.; Birru, A.K. Microstructure and mechanical properties of aluminium metal matrix composites with addition of bamboo leaf ash by stir casting method. Trans. Nonferrous Met. Soc. China 2017, 27, 2555-2572. [CrossRef]

61. Aigbodion, V.S.; Hassan, S.B.; Nyior, G.B.; Ause, T. Effect of Bagasse ash reinforcement on the wear behaviour of Al-Cu$\mathrm{Mg} /$ Bagasse ash particulate composites. Acta Met. Sin. 2010, 23, 81-89.

62. Atuanya, C.U.; Aigbodion, V.S. Evaluation of Al-Cu-Mg alloy/bean pod ash nanoparticles synthesis by double layer feeding-stir casting method. J. Alloys Compd. 2014, 601, 251-259. [CrossRef]

63. Atuanya, C.U.; Ibhadode, A.O.A.; Dagwa, I.M. Effects of breadfruit seed hull ash on the microstructures and properties of Al-Si-Fe alloy/breadfruit seed hull ash particulate composites. Results Phys. 2012, 2, 142-149. [CrossRef]

64. Ochieze, B.Q.; Nwobi-Okoye, C.C.; Atamuo, P.N. Experimental study of the effect of wear parameters on the wear behavior of A356 alloy/cow horn particulate composites. Def. Technol. 2018, 14, 77-82. [CrossRef]

65. Alaneme, K.K.; Bodunrin, M.O.; Awe, A.A. Microstructure, mechanical and fracture properties of groundnut shell ash and silicon carbide dispersion strengthened aluminium matrix composites. J. King Saud Univ. Sci. 2018, 30, 96-103. [CrossRef]

66. Hima Gireesh, C.; Durga Prasad, K.G.; Ramji, K.; Vinay, P.V. Mechanical Characterization of Aluminium Metal Matrix Composite Reinforced with Aloe vera powder. Mater. Today Proc. 2018, 5, 3289-3297. [CrossRef]

67. Omole, S.O.; Akinfolarin, J.F.; Oluyori, R.T. Assessment of Hardness and Tensile Properties of Stir-Cast Aluminium Matrix Reinforced with Tetracarpidium Conophorum Kernel. Int. J. Eng. 2014, 4, 8269.

68. Parande, G.; Manakari, V.; Kopparthy, S.D.S.; Gupta, M. Utilizing Low-Cost Eggshell Particles to Enhance the Mechanical Response of Mg-2.5Zn Magnesium Alloy Matrix. Adv. Eng. Mater. 2018, 20, 1700919. [CrossRef]

69. Dwivedi, S.P.; Sharma, S.; Mishra, R.K. A comparative study of waste eggshells, $\mathrm{CaCO}_{3}$, and SiC-reinforced AA2014 green metal matrix composites. J. Compos. Mater. 2016, 51, 2407-2421. [CrossRef]

70. Hassan, S.B.; Aigbodion, V.S. Effects of eggshell on the microstructures and properties of Al-Cu-Mg/eggshell particulate composites. J. King Saud Univ.-Eng. Sci. 2015, 27, 49-56. [CrossRef]

71. Jannet, S.; Raja, R.; Rajesh Ruban, S.; Khosla, S.; Sasikumar, U.; Sai, N.B.; Teja, P.M. Effect of egg shell powder on the mechanical and microstructure properties of AA 2024 metal matrix composite. Mater. Today Proc. 2021, 44, 135-140. [CrossRef]

72. Ononiwu, N.H.; Ozoegwu, C.G.; Madushele, N.; Akinlabi, E.T. Effects of carbonised eggshells on the mechanical properties, microstructure and corrosion resistance of AA1050 of metal matrix composites. Adv. Mater. Process. Technol. 2021, 1-12. [CrossRef]

73. Parande, G.; Manakari, V.; Sharma Kopparthy, S.D.; Gupta, M. A study on the effect of low-cost eggshell reinforcement on the immersion, damping and mechanical properties of magnesium-zinc alloy. Compos. Part B Eng. 2020, 182, 107650. [CrossRef]

74. Kolawole, M.Y.; Aweda, J.O.; Abdulkareem, S.; Bello, S.A.; Ali, A.; Iqbal, F. Influence of calcined snail shell particulates on mechanical properties of recycled aluminium alloy for automotive application. Acta Period. Technol. 2020, 51, 163-180. [CrossRef]

75. Asafa, T.B.; Durowoju, M.O.; Oyewole, A.A.; Solomon, S.O.; Adegoke, R.M.; Aremu, O.J. Potentials of Snailshell as a Reinforcement for Discarded Aluminum Based Materials. Int. J. Adv. Sci. Technol. 2015, 84, 1-8. [CrossRef]

76. Seetharaman, S.; Gupta, M. Fundamentals of Metal Matrix Composites, In: Dermot Brabazon, Encyclopedia of Materials: Composites; Elsevier: Amsterdam, The Netherlands, 2021; ISBN 978-0-12-803581-8. 
77. Huda, D.; El Baradie, M.A.; Hashmi, M.S.J. Metal-matrix composites: Materials aspects. Part II. J. Mater. Process. Tech. 1993, 37, 529-541. [CrossRef]

78. Harrigan, W.C. Commercial processing of metal matrix composites. Mater. Sci. Eng. A 1998, 244, 75-79. [CrossRef]

79. Gupta, M.; Lai, M.O.; Soo, C.Y. Processing-microstructure-mechanical properties of an Al-Cu/SiC metal matrix composite synthesized using disintegrated melt deposition technique. Mater. Res. Bull. 1995, 30, 1525-1534. [CrossRef]

80. Wood, J. Spray atomisation and deposition. Surf. Eng. 1997, 13, 28. [CrossRef]

81. Spray, M.; Spray, C. Fabrication of Metal Matrix Composites by Co-Deposition. Chem. Vap. Depos. 2018. Available online: https:/ /www. substech.com/dokuwiki/doku.php?id=fabrication_of_metal_matrix_composites_by_co-deposition (accessed on 4 January 2022).

82. Malaki, M.; Xu, W.; Kasar, A.K.; Menezes, P.L.; Dieringa, H.; Varma, R.S.; Gupta, M. Advanced Metal Matrix Nanocomposites. Metals 2019, 9, 330. [CrossRef]

83. Thümmler, F.; Thomma, W. The sintering process. Metall. Rev. 1967, 12, 69-108. [CrossRef]

84. Gupta, M.; Sharon, N.M.L. Magnesium, Magnesium Alloys, and Magnesium Composites; John Wiley \& Sons: Hoboken, NJ, USA, 2010; ISBN 9780470494172

85. Penchal Reddy, M.; Shakoor, R.A.; Mohamed, A.M.A.; Gupta, M. Microwave rapid sintering of al-metal matrix composites: A review on the effect of reinforcements, microstructure and mechanical properties. Metals 2016, 6, 143.

86. Prasad, N. Development and Characterization of Metal Matrix Composite Using Red Mud an Industrial Waste for Wear Resistant Applications. Ph.D. Thesis, National Institute of Technology, Rourkela, India, 2006.

87. Gikunoo, E. Effect of Fly Ash Particles on the Mechanical Properties and Microstructure of Aluminium Casting Alloy A535. Master's Thesis, University of Saskatchewan, Saskatoon, SK, Canada, November 2004.

88. Krupakara, P.V. Corrosion characterization of Al6061/red mud metal matrix composites. Port. Electrochim. Acta 2013, 31, 157-164. [CrossRef]

89. Chandla, N.K.; Jawalkar, C.S.; Suri, N.M. Review on Analysis of Stir Cast Aluminium Metal Matrix Composite from AgroIndustrial Wastes. i-Manager's J. Mater. Sci. 2017, 5, 35.

90. Heidarzadeh, A.; Mohammadzadeh, R.; Brabazon, D. Green Materials and Production of Metallic Composite Materials. Encycl. Mater. Compos. 2021, 2, 744-757. [CrossRef]

91. Shi, Y.; Song, Q. Green research on the application of bamboo material on home appliances. In Proceedings of the 2010 IEEE 11 th International Conference on Computer-Aided Industrial Design \& Conceptual Design 1, Yiwu, China, 17-19 November 2010; Volume 2, pp. 897-900. 